"This accepted author manuscript is copyrighted and published by Elsevier. It is posted here by agreement between Elsevier and MTA. The definitive version of the text was subsequently published in Appl. Catal. B: Environ. 174, 455-470 (2015), DOI: 10.1016/j.apcatb.2015.03.031. Available under license CC-BY-NC-ND."

\title{
Preparation and characterization of novel $\mathrm{Ti}_{0.7} \mathrm{~W}_{0.3} \mathrm{O}_{2}-\mathrm{C}$ composite materials for Pt-based anode electrocatalysts with enhanced $\mathrm{CO}$ tolerance
}

\author{
Dorottya Gubán, Irina Borbáth,* Zoltán Pászti, István Sajó, Eszter Drotár, Mihály \\ Hegedűs, András Tompos \\ Institute of Materials and Environmental Chemistry, Research Centre for Natural Sciences \\ Hungarian Academy of Sciences, 1117 Budapest, Magyar Tudósok körútja 2, Hungary
}

\begin{abstract}
Ti-based electroconductive mixed oxides were deposited onto activated carbon by using three different sol-gel-based multistep synthesis routes. As demonstrated by X-ray diffraction, high crystallinity of the tungsten-loaded rutile was achieved by a sequence of annealing in inert atmosphere at $750^{\circ} \mathrm{C}$ and a short reductive treatment at $650^{\circ} \mathrm{C}$. Formation of the rutile phase on the carbon support before the high temperature treatment has been proved to be the prerequisite for complete $\mathrm{W}$ incorporation into the rutile lattice. The structural and compositional properties of the mixed oxides were explored by transmission electron microscopy, temperature programmed reduction and X-ray photoelectron spectroscopy. Anode electrocatalysts were formulated by loading the composite of the activated carbon and the Ti-based electroconductive mixed oxides with 40 wt $\%$ Pt. Enhanced $\mathrm{CO}$ tolerance along with considerable stability was demonstrated for the electrocatalyst prepared using the $\mathrm{Ti}_{0.7} \mathrm{~W}_{0.3} \mathrm{O}_{2}$ - $\mathrm{C}$ composite material with high degree of $\mathrm{W}$ incorporation.
\end{abstract}

Keywords: PEM fuel cells, anode electrocatalysts, conducting Ti-W mixed oxides, composite materials, CO-tolerance, XRD, XPS, TPR.

(*) Corresponding author: Irina Borbáth, email: borbath.irina@ttk.mta.hu, phone: +3613826916 


\section{Introduction}

The most effective anode electrocatalysts in proton exchange membrane (PEM) fuel cells are based on Pt. Key requirements for the implementation of this type of fuel cells are reducing the amount of $\mathrm{Pt}$ while simultaneously increasing the metal dispersion and $\mathrm{CO}$ tolerance of the anode electrocatalysts. $\mathrm{CO}$ tolerance has to be improved as hydrogen fuel generally contains $\mathrm{CO}$ impurity that poisons $\mathrm{Pt}$. It is found that the $\mathrm{CO}$ can adsorb very strongly on the Pt surface, blocking the active sites for the hydrogen oxidation reaction and causing a large decrease in the electrode performance.

In order to reduce this poisoning issue, several approaches have been attempted. A common approach consists of the utilization of a second oxophilic metal in the Ptbased anode catalyst. The second element is less noble than Pt and thus activates water at lower potential leading to accelerated $\mathrm{CO}_{2}$ formation rates.

There are numerous studies focused on W-based, CO-tolerant electrocatalysts, either W-modified Pt electrodes or Pt deposited on the surface of $\mathrm{WO}_{3}$ oxide [1-5]. It has been demonstrated that the promotional effect of tungsten added to anode catalyst is: (i) to provide the necessary $\mathrm{OH}_{\mathrm{ad}}$ species at less positive potentials than Pt (the socalled "bifunctional mechanism"); (ii) to modify the electronic interactions between Pt and the $\mathrm{CO}$ adsorbate (the "electronic effect"); and (iii) to increase catalytic activity through "hydrogen spill-over" effect [6-9]. In agreement with the bifunctional mechanism, the co-catalytic activity is supposed to be due to a rapid and easy change of the oxidation state of tungsten.

Atomic hydrogen can be reversibly stored in tungsten trioxide [10]. In acidic solutions $\mathrm{H}_{\mathrm{ad}}$ produced from dehydrogenation of methanol on Pt surface can "spillover" to the surface of $\mathrm{WO}_{3}$ to form hydrogen tungsten bronzes $\mathrm{H}_{\mathrm{x}} \mathrm{WO}_{3}(0.3<\mathrm{x}<0.5)$, which is an acid resistant metallic conductor. Such compounds could function as intermediates in the anodic oxidation of hydrogen, providing an alternative path for the reaction [7]:

$$
\mathrm{WO}_{3}+\mathrm{x} \mathrm{Pt}-\mathrm{H} \rightarrow \mathrm{H}_{\mathrm{x}} \mathrm{WO}_{3}+\mathrm{Pt} \rightarrow \mathrm{WO}_{3}+\mathrm{x} \mathrm{e}^{-}+\mathrm{x} \mathrm{H}^{+}
$$

The proton conducting tungsten bronze also provides rapid hydrogen oxidation leading to the improvement of the overall catalytic activity [6,7].

For the Pt-Mo system Santiago et al. [11] proposed that lower CO concentration can be achieved in the gas channels of the electrode by removing $\mathrm{CO}$ with a heterogeneous chemical reaction catalyzed by Mo sites, i.e., the well-known water gas shift reaction (WGSR), which involves the conversion of $\mathrm{CO}$ to $\mathrm{CO}_{2}$ without the direct 
participation of protons and electrons. It has been proposed $[2,12]$ that by using $\mathrm{Pt} / \mathrm{WO}_{\mathrm{x}}$ electrocatalysts, the occurrence of WGSR acting together with the bifunctional mechanism also cannot be discarded.

It is known that tungsten is easily oxidized at low potentials. $\mathrm{WO}_{3}$ is an n-type semiconductor with a band gap of 2.6-2.7 eV and it cannot be used in fuel cells due to its low electronic conductivity, which derives from the fact that $\mathrm{W}$ is in its highest oxidation state. Usually carbon black has been added to $\mathrm{Pt} / \mathrm{WO}_{\mathrm{x}}$ catalysts to ensure electronic percolation in the electrodes during the electrochemical measurements [8]. Moreover, in the literature a variety of synthesis procedures of different carbonsupported $\mathrm{Pt}-\mathrm{WO}_{\mathrm{x}}$ composite materials are available $[9,13]$.

$\mathrm{TiO}_{2}$ is an n-type semiconductor having a wide band gap (3.0-3.5 eV depending on the primary particle size and other properties). Due to its excellent mechanical, chemical and redox stability, low cost, non-toxicity and corrosion resistance in acidic environment, $\mathrm{TiO}_{2}$ has been widely used for optical coatings, solar cells, photocatalytic water splitting and anti-reflection coatings [1,14-15]. There are reports on its application as a humidity sensor and high temperature oxygen sensor [16]. $\mathrm{TiO}_{2}$ has also been used as a catalyst support in fuel cells, even though its electronic conductivity is much lower than that of conventional carbon supports. It has been demonstrated that the conductivity of pure titania can be substantially improved by introduction of oxygen vacancies or by cation substitution. For this purpose various transition metals can be applied because they would have an excess or deficit of electrons when at the oxidation state of four. Moreover, dopant metals are usually selected on the basis of their ionic radii similarity to that of $\mathrm{Ti}^{4+}$ (effective ionic radii $r_{\text {ion }}\left(\mathrm{Ti}^{4+}\right)=60.5 \mathrm{pm}, r_{\text {ion }}\left(\mathrm{W}^{6+}\right)=60$ pm) [17-18]. Electroconductive $\mathrm{Ti}_{0.7} \mathrm{~W}_{0.3} \mathrm{O}_{2}$ mixed oxide has already been used as a support for $\mathrm{Pt}[1,19]$. These materials showed unique CO-tolerant electrocatalytic activity for hydrogen oxidation compared to commercial catalysts [1]. It has been mentioned that sufficient electronic conductivity was ensured by adding $20 \mathrm{wt} \% \mathrm{C}$ to the $\mathrm{Pt} / \mathrm{Ti}_{0.7} \mathrm{~W}_{0.3} \mathrm{O}_{2}$ to prepare the catalyst ink.

It is well known that titanium dioxide exists in three main polymorphic phases: rutile, anatase and brookite. Large number of preparation methods of $\mathrm{TiO}_{2}$ have been investigated and reported in the literature [16,20-23]. Hydrothermal methods and sol-gel processes using titanium alkoxides or inorganic salts as starting precursors usually yield nanocrystalline titanium dioxide. Cheng et al. [24] demonstrated that by selecting appropriate hydrothermal conditions, uniform nanosize $\mathrm{TiO}_{2}$ (rutile or anatase) particles 
could be obtained. The effect of additives on the formed phase and its morphology has been studied by the $\mathrm{Ti}-\mathrm{H}_{2} \mathrm{O}_{2}$ oxidation-hydrothermal combination method at room temperature [25]. Tungsten trioxide nanostructures can also be prepared by a low temperature hydrothermal route [26-27]. The recently developed microwave-assisted hydrothermal (M-H) technique [28-29], which is superior to conventional hydrothermal process due to (i) fast heating to the temperature of treatment and (ii) extremely rapid kinetics of crystallization, was successfully used for the $\mathrm{TiO}_{2}$ synthesis [29-30]. Moreover, various low temperature sol-gel based methods can be found in the literature for the preparation of pure rutile $\mathrm{TiO}_{2}$ nanoparticles [16,31-35]. Recently, an intense effort has also been devoted to loading $\mathrm{TiO}_{2}$ on activated carbon using sol-gel technique [36-39]. It has been shown [36] that improved photocatalytic efficiency of $\mathrm{TiO}_{2} / \mathrm{C}$ composite materials in the degradation of organic pollutants is caused by the synergistic effect of adsorption by activated carbon and photocatalytic decomposition by $\mathrm{TiO}_{2}$.

It has been demonstrated [40-42] that the application of sol-gel hydrothermal (solvothermal) synthesis provides a possible way to synthesize new mixed titaniumbased $\mathrm{MTiO}_{3}(\mathrm{M}=\mathrm{Mn}, \mathrm{Pb}, \mathrm{Ba})$ oxides. With respect to the preparation of nanostructured $\mathrm{Ti}_{(1-\mathrm{x})} \mathrm{W}_{\mathrm{x}} \mathrm{O}_{2}$ materials the investigation of new types of photocatalysts based on tungsten-doped $\mathrm{TiO}_{2}$ systems is in the focus [15,43-44]. It has been shown [43] that $\mathrm{W}$ doping and hydrothermal treatment improves significantly the visible-light photoactivity of $\mathrm{TiO}_{2}$ synthesized by the sol-gel method.

Contrary to $\mathrm{WO}_{3}$, which is an n-type semiconductor, $\mathrm{WO}_{2}$ is a conductive material with a distorted rutile structure with W-W pair bonding. Unfortunately, it is thermodynamically stable only over a narrow range of potentials (around $-0.1 \mathrm{~V}$ ) [19,45-46]. Although substitutional incorporation of $\mathrm{W}$ into anatase up to 20 atomic \% concentration is feasible [45], it has been suggested that tungsten-doped rutile with $\mathrm{W}^{4+}$ as the dominant dopant ionic species performs better as fuel cell electrocatalyst in terms of corrosion resistance and electric conductance [46]. Although the expected percolation limit for near-neighbor W-O-W connectivity is near $x=0.5$ (where $x$ is the mole fraction of $\mathrm{WO}_{2}$ in $\mathrm{TiO}_{2}$ ), DFT calculations [46] predict metallic conductivity from overlap of occupied W $5 \mathrm{~d}$ orbitals with orbitals of neighboring $\mathrm{O}$ and Ti even at much lower concentrations of $\mathrm{W}$.

In this contribution our results obtained in the development of composites of activated carbon and $\mathrm{Ti}_{(1-\mathrm{x})} \mathrm{W}_{\mathrm{x}} \mathrm{O}_{2}$ mixed oxides are shown. This paper describes the use of three different sol-gel-based multistep synthesis routes for the preparation of highly 
crystallized $\mathrm{Ti}_{0.7} \mathrm{~W}_{0.3} \mathrm{O}_{2}$ rutile phase in the presence of activated carbon with high rutile/anatase ratio and exclusive incorporation of $\mathrm{W}^{4+}$ into the rutile crystal-lattice. The main goal was to study the influence of the experimental conditions, mainly the preparation method used and the multistep heat treatment applied on i) the rutile/anatase phase ratio, ii) oxidation state of $\mathrm{W}$, and iii) presence or absence of free $\mathrm{WO}_{3}$ and/or $\mathrm{WO}_{2}$ phases, not incorporated into the rutile crystal-lattice. Efforts were made to find the optimum experimental conditions with the aim to get $\mathrm{Pt} / \mathrm{Ti}_{0.7} \mathrm{~W}_{0.3} \mathrm{O}_{2}-\mathrm{C}$ catalysts with good electrochemical stability and enhanced CO tolerance.

\section{Experimental section}

\subsection{Synthesis of $50 \mathrm{Ti}_{0.7} \mathrm{~W}_{0.3} \mathrm{O}_{2}-50 \mathrm{C}$ materials}

Ti-based electroconductive mixed oxides have been prepared by using sol-gelbased multistep synthesis routes I, II and III, as shown in Scheme 1. In all three synthesis routes titanium-isopropoxide $\left(\mathrm{Ti}(\mathrm{O}-\mathrm{i}-\mathrm{Pr})_{4}\right.$, Aldrich, 97\%) and ammonium metatungstate hydrate $\left(\left(\mathrm{NH}_{4}\right)_{6} \mathrm{H}_{2} \mathrm{~W}_{12} \mathrm{O}_{40}\right.$, Fluka, 99\%) have been used as precursor compounds. In each synthesis methods presented the expected composition of the mixed oxide was $\mathrm{Ti}_{0.7} \mathrm{~W}_{0.3} \mathrm{O}_{2}$ and the mass ratio of the mixed oxide to the activated carbon was 50:50.

\subsubsection{Microwave-assisted solvothermal synthesis (route I)}

In the first synthesis route a microwave-assisted solvothermal synthesis has been accomplished. Titanium-isopropoxide $(430 \mu \mathrm{l})$ was solved in $15 \mathrm{ml}$ of absolute ethanol. Then the solution was cooled down to $4{ }^{\circ} \mathrm{C}$ and $10 \mathrm{ml}$ of ethanol-water mixture $(1: 1)$ was added dropwise under stirring. After 30 minutes, $\left(\mathrm{NH}_{4}\right)_{6} \mathrm{H}_{2} \mathrm{~W}_{12} \mathrm{O}_{40}(158 \mathrm{mg})$ and 1 $\mathrm{cm}^{3}$ of concentrated $\mathrm{HNO}_{3}$ have been added to the sol. The mixture was stirred vigorously for additional 3 hours at room temperature (RT) and then it was transferred to a Teflon lined autoclave. Before sealing and adjusting the pressure with nitrogen, 250 mg of activated carbon (Black Pearls 2000) was added to the mixture. After that, the autoclave was treated at $175^{\circ} \mathrm{C}$ for 3 hours in a microwave reactor (Anton Paar GmbH Synthos 3000) equipped with 2 magnetrons generating unpulsed microwaves at a frequency of $2.45 \mathrm{GHz}$ with power of $800 \mathrm{~W}$. The precipitates were then washed with deionized water by centrifugation, and dried at $80{ }^{\circ} \mathrm{C}$ overnight. Finally, the dried powder was calcined in air at $350^{\circ} \mathrm{C}$ for 2 hours. 


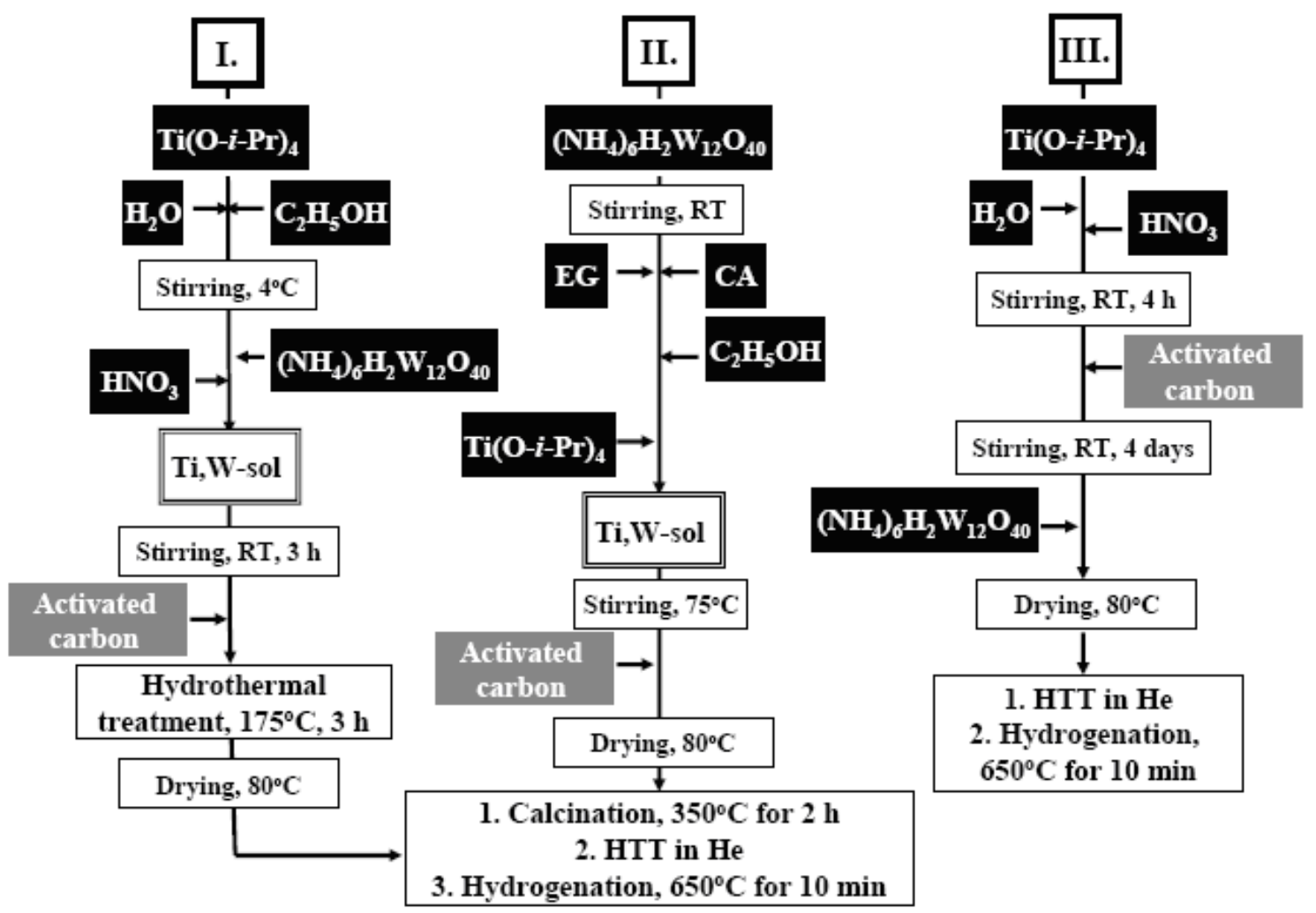

Scheme 1. Flow chart for preparing $50 \mathrm{Ti}_{0.7} \mathrm{~W}_{0.3} \mathrm{O}_{2}-50 \mathrm{C}$ composite materials by using sol-gel-based multistep synthesis routes I, II and III.

\subsubsection{Sol-gel synthesis (route II)}

Similarly to Ref. [1], in the second synthesis route a sol-gel based multistep synthesis involving in situ polymerization of citric acid (CA) and ethylene glycol (EG) was used for the preparation of the composite materials. Detailed procedure for the preparation of $50 \mathrm{Ti}_{0.7} \mathrm{~W}_{0.3} \mathrm{O}_{2}-50 \mathrm{C}$ materials by route II was as follows: $\left(\mathrm{NH}_{4}\right)_{6} \mathrm{H}_{2} \mathrm{~W}_{12} \mathrm{O}_{40}$ $(158 \mathrm{mg})$ was solved in $1 \mathrm{ml}$ of water and then $18 \mathrm{ml}$ of ethanol, $130 \mu \mathrm{l}$ of EG and 716 $\mathrm{mg}$ of CA were added to the solution. Titanium-isopropoxide $(430 \mu \mathrm{l})$ was added dropwise to the solution. The sol was stirred at $75{ }^{\circ} \mathrm{C}$ until a clear gel is formed, and then $250 \mathrm{mg}$ of activated carbon was added. The gel was dried at $80{ }^{\circ} \mathrm{C}$ overnight and then it was calcined in air at $350{ }^{\circ} \mathrm{C}$ for 2 hours.

In order to facilitate the comparison of the electrochemical behaviour of catalysts based on $\mathrm{Ti}_{0.7} \mathrm{~W}_{0.3} \mathrm{O}_{2}$ - $\mathrm{C}$ composite materials and physical mixtures, carbonfree $\mathrm{Ti}_{0.7} \mathrm{~W}_{0.3} \mathrm{O}_{2}$ mixed oxide was also prepared by this sol-gel method according to Ref. [1]. 


\subsubsection{Modified sol-gel synthesis (route III)}

In the third synthesis route another sol-gel synthesis has been accomplished, which is a novel variant of the preparation method of Yin et al. [32] for low temperature synthesis of pure rutile $\mathrm{TiO}_{2}$ powders, specifically modified for room temperature deposition of rutile $\mathrm{TiO}_{2}$ on activated carbon. In the first step rutile phase titaniumdioxide was formed on the activated carbon at RT. Titanium-isopropoxide (430 $\mu \mathrm{l})$ was added dropwise to distilled water $(12 \mathrm{ml})$ under nitrogen atmosphere and vigorous stirring. Transparent acidic $\mathrm{TiO}_{2}$ colloidal solution was obtained by adding concentrated $\mathrm{HNO}_{3}(910 \mu \mathrm{l})$ to the freshly prepared sol and then it was stirred at RT for 4 hours. Activated carbon $(250 \mathrm{mg}$ ) suspended in $10 \mathrm{ml}$ of water was added to the sol and the suspension was aged for 4 days with stirring. In additional experiments the influence of the duration of RT aging of the Ti-sol in the presence of carbon from 0.5 up to 4 days was also studied. After the aging, $\left(\mathrm{NH}_{4}\right)_{6} \mathrm{H}_{2} \mathrm{~W}_{12} \mathrm{O}_{40}(158 \mathrm{mg})$ was added and the solution was evaporated at $80^{\circ} \mathrm{C}$. The powder was dried at $80{ }^{\circ} \mathrm{C}$ overnight.

\subsubsection{High temperature treatment (HTT) and reduction}

The obtained solids have been submitted to multistep heat treatments. In synthesis routes I and II the multistep heat treatment applied after the drying procedure at $80^{\circ} \mathrm{C}$ was (i) air-calcination at $350^{\circ} \mathrm{C}$, (ii) $\mathrm{HTT}$ in $\mathrm{He}$ at $\mathrm{T}=750-800^{\circ} \mathrm{C}$ and finally (iii) reduction in $\mathrm{H}_{2}$ at $650^{\circ} \mathrm{C}$. In case of the synthesis route III the step of calcination in air at $350^{\circ} \mathrm{C}$ was omitted (see Scheme 1).

Upon using the samples prepared by synthesis route $I$, the influence of the final temperature and duration of the HTT in helium was studied. The samples prepared by synthesis route II and III were treated in helium at $750^{\circ} \mathrm{C}$ for 8 hours.

In all cases the following reduction procedure was applied: the samples were cooled down to $650^{\circ} \mathrm{C}$ and then reduced in hydrogen-water mixture $\left(\mathrm{H}_{2}: \mathrm{H}_{2} \mathrm{O}=95: 5 \mathrm{v} / \mathrm{v}\right.$ ratio) for 10 minutes and cooled down in helium to RT.

\subsection{Synthesis of $40 \mathrm{wt} \% \mathrm{Pt} / 50 \mathrm{Ti}_{0.7} \mathrm{~W}_{0.3} \mathrm{O}_{2}-50 \mathrm{C}$ electrocatalysts}

All types of $\mathrm{Ti}_{0.7} \mathrm{~W}_{0.3} \mathrm{O}_{2}-\mathrm{C}$ composite materials and the pure activated carbon have been loaded with $40 \mathrm{wt} \% \mathrm{Pt}$ via the $\mathrm{NaBH}_{4}$-assisted ethylene-glycol reduction method [47]. $\mathrm{H}_{2} \mathrm{PtCl}_{6}(333 \mathrm{mg}$ ) was solved in $50 \mathrm{ml}$ ethanol and $200 \mathrm{mg}$ of the support material was suspended in the solution. A solution prepared by the reaction of $\mathrm{NaBH}_{4}$ 
$(590 \mathrm{mg})$ and EG $(7.4 \mathrm{ml})$ was added dropwise to the suspension at $65^{\circ} \mathrm{C}$ with stirring. After 3 hours of stirring at $65^{\circ} \mathrm{C}, 30 \mathrm{ml} 0.5 \mathrm{M} \mathrm{HCl}$ was added to the suspension and stirred for an additional 2.5 hours at RT to deposit the Pt particles onto the support material. The material was washed with water by centrifugation and dried at $80{ }^{\circ} \mathrm{C}$ overnight.

The $40 \mathrm{wt} \% \mathrm{Pt} / 50 \mathrm{Ti}_{0.7} \mathrm{~W}_{0.3} \mathrm{O}_{2}-50 \mathrm{C}$ electrocatalysts prepared were denoted hereafter as $\mathrm{Pt} / \mathrm{Ti}_{0.7} \mathrm{~W}_{0.3} \mathrm{O}_{2}$ - $\mathrm{C}$ (in all composite materials the $\mathrm{Ti}_{0.7} \mathrm{~W}_{0.3} \mathrm{O}_{2} / \mathrm{C}$ ratio in weight $\%$ was 50:50).

\subsection{Physicochemical characterization}

The powder X-ray diffraction (XRD) patterns were obtained in a Philips model PW 3710 based PW 1050 Bragg-Brentano parafocusing goniometer using $\mathrm{CuK}_{\alpha}$ radiation $(\lambda=0.15418 \mathrm{~nm})$, graphite monochromator and proportional counter. Silicon powder (NIST SRM 640) was used as an internal standard and the scans were evaluated with profile fitting methods. The cell parameters of the crystalline phases were determined from the fitted d-values. Crystallite sizes were calculated from reflection line broadening using the Scherrer-equation.

Transmission Electron Microscopy (TEM) studies of the samples were made by use of a FEI Morgagni 268D type transmission electron microscope (accelerating voltage: $100 \mathrm{kV}$, W-filament). The fresh samples and those used in electrochemical stability tests were prepared by grinding and dispersing of the resulted powder in ethanol using an ultrasonic bath. After electrochemical experiments catalysts were removed from the electrodes with isopropanol in an ultrasonic bath. A volume of the obtained suspension was pipetted onto a carbon coated copper grid.

The average diameter was calculated by measuring the diameters of no less than 350 randomly selected metal particles from the non-aggregated areas in at least tree micrographs of each sample.

Energy Dispersive X-ray Spectrometry (EDS) analysis was performed with an INCA (Oxford Instruments Ltd.) detector and the INCAEnergy software package. EDS analysis of individual particles was possible by using ZEISS EVO 40XVP Scanning Electron Microscope (accelerating voltage: $20 \mathrm{kV}$, W-filament).

Temperature Programmed Reduction (TPR) experiments and BET measurements were carried out in a commercial equipment (ASDI RXM 100Advanced Scientific Designs Inc.). TPR experiments were performed in a quartz flow 
reactor. A thermal conductivity detector was adapted to monitor the $\mathrm{H}_{2}$ consumption during a TPR run. The profiles were automatically recorded with a computer and the area under the TPR curve was integrated. The quantity of the $\mathrm{H}_{2}$ consumption was defined by calibrating the detector with a well-known volume and concentration of hydrogen containing gas mixture. The samples were heated at $10^{\circ} \mathrm{C} \mathrm{min}^{-1}$ from room temperature up to $850-950^{\circ} \mathrm{C}$. The reductive mixture $\left(5.2 \mathrm{v} / \mathrm{v} \% \mathrm{H}_{2}-\mathrm{Ar}\right)$ was introduced to the reactor with a flow rate of $40 \mathrm{~cm}^{3} \mathrm{~min}^{-1}$.

The specific surface area $\left(\mathrm{S}_{\mathrm{BET}}\right)$ was determined by nitrogen adsorption (BET method). Prior to the measurement the sample was pretreated in $\mathrm{He}$ flow at $750{ }^{\circ} \mathrm{C}$ for 8 $\mathrm{h}$ then evacuated at $10^{-6}$ Torr and cooled down to the temperature of liquid nitrogen.

X-ray photoelectron spectroscopy (XPS) measurements were performed on carbon-free $\mathrm{Ti}_{0.7} \mathrm{~W}_{0.3} \mathrm{O}_{2}$ samples from synthesis route II and on $50 \mathrm{Ti}_{0.7} \mathrm{~W}_{0.3} \mathrm{O}_{2}-50 \mathrm{C}$ composites prepared using route III. The experiments were carried out using an EA125 electron spectrometer manufactured by OMICRON Nanotechnology GmbH (Germany). The photoelectrons were excited by unmonochromatized $\operatorname{MgK} \alpha(1253.6 \mathrm{eV})$ or $\mathrm{AlK} \alpha$ $(1486.6 \mathrm{eV})$ radiation. Spectra were recorded in the Constant Analyser Energy mode of the energy analyser with $30 \mathrm{eV}$ pass energy resulting in a spectral resolution of $1 \mathrm{eV}$.

For XPS experiments the samples in the form of fine powder were suspended in hexane. Drops of this suspension were placed on standard OMICRON sample plates; after evaporation of hexane catalyst coatings with sufficient adhesion and electric conductivity were obtained. Samples were analyzed in their "as received" state. No change during the X-ray exposure was seen, indicating that radiation damage in the samples was negligible.

Binding energies of the carbon-supported samples were referenced to the main component of the C 1s spectrum of the support (graphite at $284.4 \mathrm{eV}$ binding energy). Data were processed using the CasaXPS software package [48] by fitting the spectra with Gaussian-Lorentzian product peaks after removing a Shirley or linear background. Nominal surface compositions were calculated using the XPS MultiQuant software package [49-50], with the assumption of homogeneous depth distribution for all components. Chemical states were identified by XPS databases [51-52] and with the help of the related literature. 


\subsection{Electrochemical characterization}

The $40 \mathrm{wt} \% \mathrm{Pt} / 50 \mathrm{Ti}_{0.7} \mathrm{~W}_{0.3} \mathrm{O}_{2}-50 \mathrm{C}$ electrocatalysts were investigated by means of cyclic voltammetry and $\mathrm{CO}_{\mathrm{ad}}$ stripping technique. For comparison the electrochemical behaviour of the initially carbon-free $40 \mathrm{wt} \% \mathrm{Pt} / \mathrm{Ti}_{0.7} \mathrm{~W}_{0.3} \mathrm{O}_{2}$ catalyst suggested by Wang et al. [1] (synthesis route II) was also studied. In this case the $\mathrm{Pt} / \mathrm{Ti}_{0.7} \mathrm{~W}_{0.3} \mathrm{O}_{2}$ catalyst was mixed with activated carbon in an agate mortar with the weight ratio of $4: 1$ before the ink preparation to ensure sufficient electronic conductivity.

The working electrode was prepared by supporting the electrocatalysts on a glassy carbon electrode $\left(\mathrm{d}=0.3 \mathrm{~cm}\right.$, geometric surface area $\left.\mathrm{A}=0.0707 \mathrm{~cm}^{2}\right)$. Before each test the glassy carbon disc was polished with $0.05 \mu \mathrm{m}$ alumina to obtain a mirror finish, followed by ultrasonic cleaning in water $(18.2 \mathrm{M} \Omega \mathrm{cm})$, isopropanol and again water to remove any traces of organic impurities. The samples under study were deposited onto the glassy carbon by means of a catalyst ink. $5 \mathrm{mg}$ of the electrocatalyst, $0.5 \mathrm{ml}$ of EG, $0.2 \mathrm{ml}$ of isopropanol and $30 \mu \mathrm{l}$ of Nafion solution (DuPont ${ }^{\mathrm{TM}} \mathrm{Nafion}^{\circledR}$ PFSA Polymer Dispersions DE 520) were dispersed in an ultrasonic bath for 45 minutes, resulting in a homogeneous ink. After ultrasonic dispersion an $1.3 \mu \mathrm{l}$ aliquot has been dropped over the glassy carbon surface and dried under an infrared lamp for 30 minutes leading to a homogeneous coating. Pt was used as counter electrode. The reference electrode was $\mathrm{Ag} / \mathrm{AgCl}$ electrode but all potentials are given on the reversible hydrogen electrode (RHE) scale. The applied electrolyte was $0.5 \mathrm{M} \mathrm{H}_{2} \mathrm{SO}_{4}$. Prior to the measurements, the electrode was activated by potential cycling 100 times in the range 0.05 and $1.25 \mathrm{~V}$ at a scan rate of $1000 \mathrm{mV} \mathrm{s}^{-1}$. After the activation procedure, cyclic voltammetric measurements were done in the potential range of 0.05-1.05 V (vs. RHE) at a scan rate of $10 \mathrm{mV} \mathrm{s}^{-1}$.

The amount of adsorbed $\mathrm{CO}\left(\mathrm{CO}_{\mathrm{ad}}\right)$ over the catalysts has been measured by $\mathrm{CO}$ stripping voltammetry in $0.5 \mathrm{M} \mathrm{H}_{2} \mathrm{SO}_{4}$. Gaseous $\mathrm{CO}$ was fed into the cell for $30 \mathrm{~min}$ while maintaining the electrode potential constant at $0.02 \mathrm{~V}$. After $\mathrm{CO}$ removal from the solution (Ar or $\mathrm{H}_{2}$ purge for $30 \mathrm{~min}$ ), the working electrode was subjected to a cyclic voltammetric measurement at a $10 \mathrm{mV} \mathrm{s}^{-1}$ scan rate between 0.05 and $1.05 \mathrm{~V}$. For comparison $\mathrm{PtRu} / \mathrm{C}$, considered as the state-of-the art CO-tolerant electrocatalyst, (Quintech C-20-/10-Pt/Ru, Pt= $20 \mathrm{wt} \%, \mathrm{Ru}=10 \mathrm{wt} \%$ on Vulcan; denoted hereafter as $\mathrm{PtRu} / \mathrm{C}$ ) was also studied in the $\mathrm{CO}_{\text {ads }}$ stripping after $\mathrm{Ar}$ and $\mathrm{H}_{2}$ purging. 
The electrochemical stability was tested by potential cycling between 0.05 and $1.25 \mathrm{~V}$ at a scan rate of $50 \mathrm{mV} \mathrm{s}^{-1}$ for 5000 cycles. The measurements took 66.7 hours. The $\mathrm{Q}_{\mathrm{H}-\mathrm{UPD}}$ charges, associated with hydrogen adsorption/desorption, were calculated using conventional baseline correction.

Relative errors were calculated as the standard deviation of at least three independent measurements. The potential errors during the measurements include inaccuracies of catalyst weighting, inhomogeneities of the catalyst suspensions and correction of double layer currents. Further systematic errors may arise from the assumption of complete catalyst wetting without any surface area loss due to contact of the Pt particles with the support. The protocol of the electrochemical measurements was previously tested on commercially available standard $40 \mathrm{wt} \% \mathrm{Pt} / \mathrm{C}$ electrocatalyst (QuinTech, C-40-Pt) with respect to the specifications from the manufacturer.

\section{Results and discussion}

\subsection{Preparation and characterization of the $50 \mathrm{Ti}_{0.7} \mathrm{~W}_{0.3} \mathrm{O}_{2}-50 \mathrm{C}$ composite materials}

The primary focus of this work was to find the optimum experimental conditions for reproducible preparation of composites of activated carbon and $\mathrm{Ti}_{(1-\mathrm{x})} \mathrm{W}_{\mathrm{x}} \mathrm{O}_{2}$ mixed oxides with high rutile/anatase $(\mathrm{R} / \mathrm{A})$ ratio and exclusive incorporation of $\mathrm{W}^{4+}$ into the rutile crystal-lattice by means of isovalent cation substitution. Three different synthesis routes were applied for the preparation of the composite materials (Scheme 1): (i) a microwave-assisted solvothermal synthesis (route I), (ii) a sol-gel process (route II) and (iii) a modified low-temperature sol-gel synthesis (route III).

The W-O distances in $\mathrm{WO}_{2}(1.97$ and $2.11 \AA)$ are very similar to the Ti-O bond length of rutile $\mathrm{TiO}_{2}$ (1.95 and $1.98 \AA$ ) [53]. Moreover, $\mathrm{WO}_{2}$ has a distored rutile structure [54], thus rutile is indeed the most promising $\mathrm{TiO}_{2}$ polymorph for isovalent tungsten incorporation. On the other hand, $\mathrm{W}^{6+}$ ions in octahedral environment have essentially the same ionic radius than that of $\mathrm{Ti}^{4+}$ ions. Accordingly, the main tasks are (i) the formation of $\mathrm{Ti}_{(1-\mathrm{x})} \mathrm{W}_{\mathrm{x}} \mathrm{O}_{2}$ rutile phase with high crystallinity in the presence of activated carbon and (ii) the transformation of $\mathrm{W}$ into oxidation state of four.

The computer modeling of a $\mathrm{Ti}_{(1-x)} \mathrm{W}_{\mathrm{x}} \mathrm{O}_{2}$ mixed oxide revealed [55] that upon tungsten incorporation into the rutile lattice the unit cell parameters and volume changes significantly. An expansion of the $a$-axis and a contraction of the $c$-axis are found due to the size difference between the $\mathrm{W}^{6+}$ and $\mathrm{W}^{4+}$ ions as well as $\mathrm{W}-\mathrm{W}$ pairing in the doped 
compound $[19,46]$. Such pairing is also seen in $\mathrm{WO}_{2}$ and is expected in the doped $\mathrm{TiO}_{2}$. The lattice distortion therefore can be used as an indicator of tungsten incorporation.

The sol-gel technique is an excellent method to prepare $\mathrm{TiO}_{2} /$ carbon composite materials with a well-developed mesoporosity into which the titania nanoparticles are well dispersed [56]. Although rutile is the thermodynamically stable phase of $\mathrm{TiO}_{2}$ at atmospheric pressure, often anatase is the primarily developing polymorph during synthesis [57]. Nevertheless, it has been shown [24] that using high acidity and concentration of the $\mathrm{Ti}$ precursor solution in sol-gel hydrothermal synthesis, the formation of the rutile phase is favoured. When the sol was aged at room temperatures in an acidic solution, crystallization of $\mathrm{TiO}_{2}$ occurred. That means $\mathrm{H}^{+}$ions in the solution rearranged the particles of amorphous precipitates, which led to the formation of crystalline $\mathrm{TiO}_{2}$. Rutile $\mathrm{TiO}_{2}$ nanocrystallines has been synthesized by Chen et al. [30] using $\mathrm{TiCl}_{4}$ and hydrochloric acid via $\mathrm{M}-\mathrm{H}$ synthesis. Based on these results, in synthesis route I titanium-isopropoxide was used as a Ti precursor compound and the $\mathrm{pH}$ was adjusted by $\mathrm{HNO}_{3}$. Synthesis route III has been focused on the preparation of rutile $\mathrm{TiO}_{2}$ phase at $\mathrm{RT}$.

\subsubsection{Optimization of the preparation of the $50 \mathrm{Ti}_{0.7} \mathrm{~W}_{0.3} \mathrm{O}_{2}-50 \mathrm{C}$ composites}

The structure of the $\mathrm{Ti}_{0.7} \mathrm{~W}_{0.3} \mathrm{O}_{2}-\mathrm{C}$ composite materials was investigated by powder X-ray diffraction measurements. The XRD and EDS techniques were used to estimate the composition of the materials, determine the lattice parameters and the average crystallite size. Correlations were sought between the experimental conditions, mainly the used preparation method and the applied multistep heat treatment and the structural properties as i) the rutile/anatase phase ratio and ii) presence or absence of free $\mathrm{WO}_{3}$ and/or $\mathrm{WO}_{2}$ phases, non incorporated into the rutile crystal-lattice.

In the course of developing a reliable preparation procedure for $\mathrm{Ti}_{0.7} \mathrm{~W}_{0.3} \mathrm{O}_{2}-\mathrm{C}$ composite materials, first activated carbon-free $\mathrm{Ti}_{0.7} \mathrm{~W}_{0.3} \mathrm{O}_{2}$ mixed oxide was prepared by sol-gel method II according to Refs. [1,19]. The original reduction process of Ref. [19] (heating with stoichiometric amount of $\mathrm{Zr}$ foil at $750^{\circ} \mathrm{C}$ for up to 2 days) was replaced with the much faster multistep heat treatment described in the Experimental section (drying, air-calcination, $8 \mathrm{~h} \mathrm{HTT}$ in He, rapid reduction in wet $\mathrm{H}_{2}$ ). Based on the XRD results presented in the second line of Table 1 , after reduction in $\mathrm{H}_{2}$ total incorporation of $\mathrm{W}$ was observed. Fine dispersed nanoparticles $(18 \mathrm{~nm})$ of almost pure rutile phase $(\mathrm{R} / \mathrm{A}=92 / 8)$ with lattice parameters of $\mathrm{Ti}_{0.7} \mathrm{~W}_{0.3} \mathrm{O}_{2}(a=4.695, c=2.910)$ and 
Table 1. Structural properties of the mixed oxides determined by XRD and their influence on the electrochemical performance of the corresponding electrocatalysts.

\begin{tabular}{|c|c|c|c|c|c|c|c|c|c|}
\hline \multirow[t]{2}{*}{ Samples } & \multicolumn{3}{|c|}{ Phase, \% } & \multirow{2}{*}{$\begin{array}{l}\text { Lattice } \\
\text { parameters, }{ }^{\text {a,b) }} \AA \\
\text { (crystallinity, \%) }\end{array}$} & \multirow{2}{*}{$\begin{array}{l}\mathbf{J}_{710 ~ m V} \\
\mathbf{m A} / \mathbf{c m}^{2}\end{array}$} & \multirow{2}{*}{$\begin{array}{l}\text { RE, } \\
\%\end{array}$} & \multirow{2}{*}{$\begin{array}{l}\text { ECSA, } \\
\mathrm{m}^{2} / \mathrm{g}_{\mathrm{Pt}}\end{array}$} & \multirow{2}{*}{$\begin{array}{l}\text { RE, } \\
\%\end{array}$} & \multirow{2}{*}{$\begin{array}{l}\text { Degree of W } \\
\text { incorporation into } \\
\text { rutile- } \mathrm{TiO}_{2} \text { crystal- } \\
\text { lattice }\end{array}$} \\
\hline & $\mathbf{R}$ & $\mathbf{A}$ & $\mathrm{WO}_{3} / \mathrm{WO}_{2}$ & & & & & & \\
\hline $\mathrm{Pt} / \mathrm{C}$ & - & - & - & - & - & - & $12.6 \pm 1.1$ & 8 & - \\
\hline$\left\{\mathrm{Pt} / \mathrm{Ti}_{0.7} \mathrm{~W}_{0.3} \mathrm{O}_{2}\right\}+\mathrm{C}^{\mathrm{d})}$ & 92 & 8 & $0 / 0$ & $\begin{array}{l}a=4.695, c=2.910 \\
(98)\end{array}$ & $0.245 \pm 0.020$ & 8 & $13.8 \pm 1.8$ & 13 & $\begin{array}{l}\text { High degree of } \mathrm{W} \\
\text { incorporation }\end{array}$ \\
\hline Route I $^{\mathrm{e})}$ & 65.5 & 33.0 & $1.5 / 0$ & $\begin{array}{l}a=4.690, c=2.910 \\
(30-35)\end{array}$ & $0.455 \pm 0.035$ & 8 & $25.9 \pm 1.7$ & 7 & Partial W incorporation \\
\hline Route II $^{\text {e) }}$ & 0 & 33 & $0 / 67$ & $\begin{array}{l}- \\
(45)\end{array}$ & $0.360 \pm 0.035$ & 10 & $19.9 \pm 1.6$ & 8 & $\begin{array}{l}\text { Segregation of anatase- } \\
\mathrm{TiO}_{2} \text { and } \mathrm{WO}_{2} \text { phases }\end{array}$ \\
\hline Route III $^{\mathrm{e}}$ & 92 & 0 & $0 / 8$ & $\begin{array}{l}a=4.670, c=2.920 \\
(98-100)\end{array}$ & $0.890 \pm 0.055$ & 6 & $33.4 \pm 4.4$ & 13 & $\begin{array}{l}\text { High degree of } \mathrm{W} \\
\text { incorporation }\end{array}$ \\
\hline
\end{tabular}

a) Lattice parameters of the rutile phase and crystallinity of the samples (the latter are given in parentheses);

b) Lattice parameters of pure rutile $\mathrm{TiO}_{2}: a=4.593 \AA, c=2.959 \AA$

c) ECSA values were calculated from the CO-stripping measurements between 0.60-0.85 V (vs. RHE);

d) After Pt deposition on $\mathrm{Ti}_{0.7} \mathrm{~W}_{0.3} \mathrm{O}_{2}$ the catalyst was mixed with active carbon in the weight ratio of $4: 1$;

e) $40 \mathrm{wt} \% \mathrm{Pt} / 50 \mathrm{Ti}_{0.7} \mathrm{~W}_{0.3} \mathrm{O}_{2}-50 \mathrm{C}$ eletrocatalysts were prepared using $50 \mathrm{Ti}_{0.7} \mathrm{~W}_{0.3} \mathrm{O}_{2}-50 \mathrm{C}$ composite materials obtained in the synthesis route $\mathrm{I}$, II and III and presented in Figure 1B.

R: rutile, A: anatase; RE: Relative error. 
high crystallinity (98\%) were obtained. However, we recognized that upon using of solgel synthesis route II in the presence of activated carbon (fourth line of Table 1) the required incorporation of $\mathrm{W}$ is hardly attainable. Accordingly, we have turned to alternate synthesis routes.
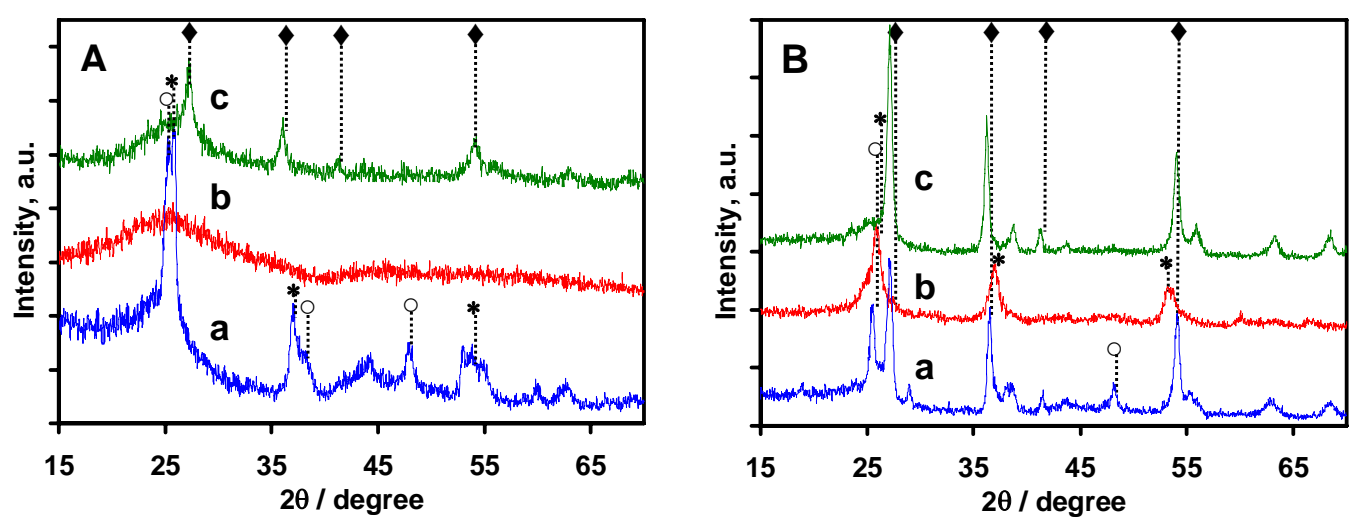

Fig. 1 XRD pattern of $50 \mathrm{Ti}_{0.7} \mathrm{~W}_{0.3} \mathrm{O}_{2}-50 \mathrm{C}$ composite materials obtained in the synthesis route I (a), II (b) and III (c) before (A) and after HTT (B). ○ Anatase, $\bullet$ Rutile, $* \mathrm{WO}_{2}$

Fig. 1A and $\mathrm{B}$ shows the XRD patterns of $\mathrm{Ti}_{0.7} \mathrm{~W}_{0.3} \mathrm{O}_{2}-\mathrm{C}$ composites obtained in the three synthesis routes before and after the multistep HTT. In Fig. 1A the XRD patterns of powders obtained before any HTT (after drying at $80^{\circ} \mathrm{C}$ overnight) are presented. Synthesis route I mainly led to a mixture of anatase and $\mathrm{WO}_{2}$, the precipitate obtained by method II was amorphous whereas only the preparation method III resulted in rutile crystallites. According to Fig. 1B and data presented in Table 1, HTT and reduction of the material from the first synthesis route resulted in a mixture of rutile and anatase phases with R/A ratio of about 2 (third line of Table 1). Multistep heat treatment of the product of synthesis route II led to a mixture of highly dispersed ( $\sim 14 \mathrm{~nm})$ totally segregated anatase- $\mathrm{TiO}_{2}$ and $\mathrm{WO}_{2}$ phases with relatively low crystallinity (crystallinity $\sim 45 \%, \mathrm{~A} / \mathrm{WO}_{2}=33 / 67$ ). We propose that the absence of crystalline rutile $\mathrm{TiO}_{2}$ phases in the composite materials prepared by route II was a reason of the presence of free, non incorporated $\mathrm{WO}_{2}$ phase.

As seen in Fig. 1B, after the heat treatments only the third preparation method leads to almost pure rutile phase with high crystallinity and high degree of tungsten 
incorporation. No signal corresponding to the metallic phase of $\mathrm{W}$ or relevant phase separation between tungsten and titanium oxides was detected. Indeed, in our previous study it has been shown [58] that formation of the $\mathrm{TiO}_{2}$ rutile phase before or during HTT in He before the reductive treatment is highly important in order to achieve exclusive incorporation of $\mathrm{W}$ into the lattice. Comparison of the results of the three synthesis routes confirms that formation of the rutile-like mixed oxide phase during annealing of an anatase-type starting material in the presence of tungsten oxides and activated carbon is highly hindered. It must be connected to the fact that the phase transformation of anatase into rutile, which occurs very rapidly in pure oxides at temperatures above $730^{\circ} \mathrm{C}$ [39], is shifted to higher temperatures in the presence of tungsten (Ref. [59]), although the negative influence of the activated carbon is also evident. In this respect therefore, the synthesis route III resulting in rutile crystallites already at RT is the preferred one for highly reproducible preparation of composites of activated carbon and rutile-like $\mathrm{Ti}_{(1-\mathrm{x})} \mathrm{W}_{\mathrm{x}} \mathrm{O}_{2}$.

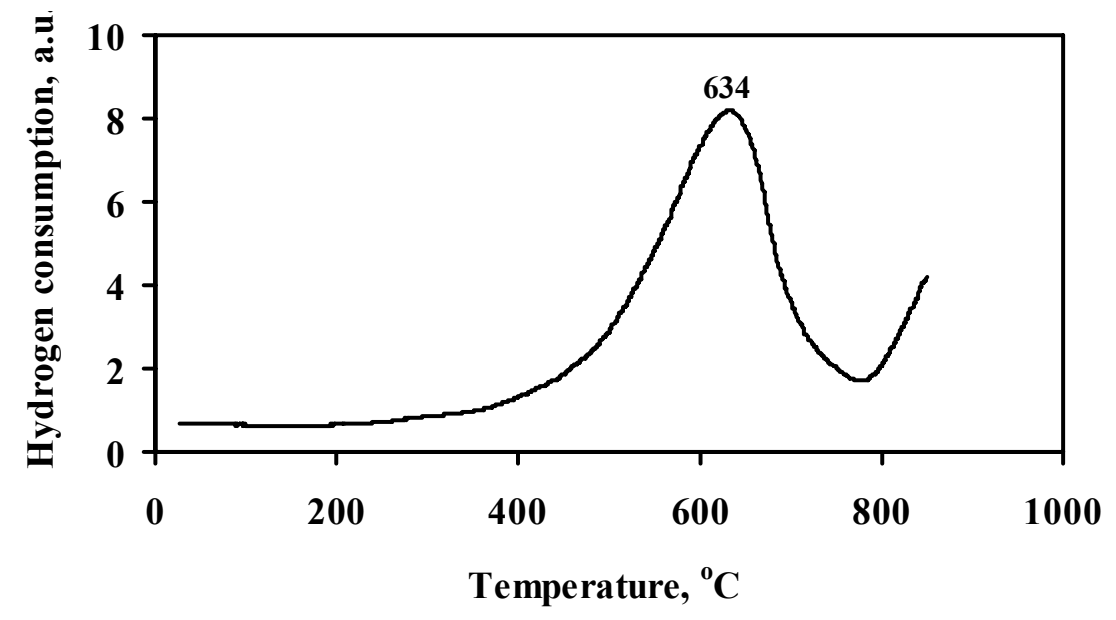

Fig. 2 Temperature Programmed Reduction (TPR) profile of the material prepared by the synthesis route III and measured with no HTT treatment (dried overnight at $80^{\circ} \mathrm{C}$ ).

We have performed an extensive study of the effect of the parameters of the multistep heat treatment process on the properties of the mixed oxide-activated carbon composites. At first the temperature range of the rapid reduction was deduced. A temperature programmed reduction experiment was carried out on the material prepared 
by the synthesis route III. No HTT treatment of the dried (overnight, at $80^{\circ} \mathrm{C}$ ) sample was applied before TPR. As shown in the TPR profile of Fig. 2, the majority of hydrogen consumption occurs in a narrow range with a maximum at $634^{\circ} \mathrm{C}$. The hydrogen consumed in the range $\sim 220^{\circ} \mathrm{C} \leq \mathrm{T} \leq 650{ }^{\circ} \mathrm{C}\left(1.65 \times 10^{-3} \mathrm{~mol} \mathrm{H}_{2} \mathrm{~g}^{-1}\right)$ was only slightly higher than the amount of $\mathrm{H}_{2}$ calculated for reduction of $\mathrm{W}^{6+}$ to $\mathrm{W}^{4+}\left(1.23 \times 10^{-3}\right.$ mol $\mathrm{H}_{2} \mathrm{~g}^{-1}$ ). The main hydrogen consuming process in this temperature range is indeed tungsten reduction [54], as ammonium tungstate species should decompose well below this temperature [60].

It has been demonstrated [54] that the reduction of tungsten oxide on titania (anatase) takes place in two well-separated steps: $\mathrm{W}^{6+} \rightarrow \mathrm{W}^{4+} \rightarrow \mathrm{W}^{0}$. It has been proposed that during reduction the $\mathrm{TiO}_{2}$ is transformed from anatase to rutile which has the same crystal structure and Ti-O bond length as $\mathrm{WO}_{2}$ and can thus facilitate and stabilize the $\mathrm{W}^{4+}$ ions. The formed $\mathrm{WO}_{2}$ can thus be immediately accommodated by the underlying rutile titania. Reduction of $\mathrm{WO}_{3}$ to $\mathrm{WO}_{2}$ in $\mathrm{WO}_{\mathrm{x}} / \mathrm{TiO}_{2}$ catalysts and relative stability of $\mathrm{W}^{4+}$ species on the $\mathrm{TiO}_{2}$ surface has been also demonstrated in Refs. [59,61].

In accordance with the above findings, the temperature of the reductive treatment was set to $650^{\circ} \mathrm{C}$.

It is known that the presence of activated carbon increases the rate of the reduction of tungsten [62]. It has been demonstrated that depending on the dispersion of the tungsten oxide the reduction of $\mathrm{WO}_{3}$ in the presence of carbon can proceed via (i) the "direct" reaction pathway to $\alpha-\mathrm{W}$ metal [63-64] or (ii) two-stage reduction, via $\mathrm{WO}_{2}$ [65], although these tungsten oxide deposits exhibit no reduction to $\mathrm{W}^{4+}$ up to $700^{\circ} \mathrm{C}$ [63]. Schubert and Lassner have reported [66-68] that upon the reduction or any heat treatment the reaction pathway strongly depended on the presence or the absence of moisture. It has been shown [62,65-68] that a higher humidity during reduction mainly leads to the formation of the intermediate $\mathrm{WO}_{2}$ oxide. Based on these results in this study wet $\mathrm{H}_{2}$ was used for the transformation of tungsten from $\mathrm{W}^{6+}$ to $\mathrm{W}^{4+}$. However, it is necessary to mention that wet hydrogen was contacted with composite materials at $650{ }^{\circ} \mathrm{C}$ only for a very short time $(10 \mathrm{~min})$, because $\mathrm{H}_{2} \mathrm{O}$ acts as a good W-transport agent at elevated temperatures and would result in an inhomogeneous final product [19].

As a next step, influence of the temperature and duration of the HTT in He preceding the reduction was investigated. Observations from XRD measurements of samples prepared by using synthesis route I, annealed in He at various parameters and reduced in $\mathrm{H}_{2}$ at $650^{\circ} \mathrm{C}$ are shown in Table 2. As emerges from the data presented in 
Table 2. Influence of the temperature and duration of HTT in He on the phase composition of the materials prepared by using synthesis route I.

\begin{tabular}{|c|c|c|c|c|c|c|}
\hline \multirow[t]{2}{*}{ Samples } & \multirow{2}{*}{$\begin{array}{c}\text { HTT, }{ }^{\circ} \mathbf{C} \\
(\text { time, h) }\end{array}$} & \multicolumn{3}{|c|}{ Phase, \% } & \multirow{2}{*}{$\begin{array}{c}\text { Lattice } \\
\left.\text { parameters, }{ }^{b}\right) \AA\end{array}$} & \multirow{2}{*}{$\begin{array}{c}\text { Size }^{c)} \\
\text { nm }\end{array}$} \\
\hline & & $\mathbf{R}$ & $\mathbf{A}$ & $\mathbf{W O}_{3} / \mathbf{W O}_{2} / \mathbf{W}$ & & \\
\hline $\mathrm{I}-1$ & $800(2)$ & 71.5 & 7.0 & $0 / 0 / 21.5$ & $a=4.630, c=2.940$ & 52 \\
\hline $\mathrm{I}-2$ & $775(2)$ & 63.5 & 31.5 & $0 / 0 / 5.0$ & $a=4.670, c=2.920$ & 30 \\
\hline I-3 & $750(2)$ & 26.0 & 45.0 & $10 / 19 / 0$ & $a=4.710, c=2.900$ & 25 \\
\hline $\mathrm{I}-4$ & $750(8)$ & 65.5 & 33.0 & $1.5 / 0 / 0$ & $a=4.690, c=2.910$ & 25 \\
\hline
\end{tabular}

a) Temperature and duration of HTT in He (the latter are given in parentheses);

b) Lattice parameters of the rutile phase. Pure rutile $\mathrm{TiO}_{2}: a=4.593 \AA, c=2.959 \AA$;

c) Average crystallite size of the rutile phase.

$\mathrm{R}$ : rutile, A: anatase. 
Table 2, in the samples treated in He for 2 hours (I-1, I-2 and I-3) the decrease of the temperature of HTT results in significant decrease of the amount and average crystallite size of the rutile phase. It is necessary to mention that treatment at $800^{\circ} \mathrm{C}$ (see sample I1 in Table 2) results in the reduction of some part of tungsten to metal. The presence of a very small part of tungsten in $\mathrm{W}^{0}$ form was still observed upon treatment in $\mathrm{He}$ at $775^{\circ} \mathrm{C}$ (sample I-2). The following decrease of the temperature to $750^{\circ} \mathrm{C}$ (see sample I-3 in Table 2) results in disappearance of $\mathrm{W}^{0}$. Unfortunately, simultaneously with the disappearance of metallic $\mathrm{W}$, a significant amount of non-incorporated tungsten was observed in the form of segregated oxide phases $\left(\mathrm{WO}_{3}, \mathrm{WO}_{2}\right)$, along with pronounced decrease of the rutile/anatase ratio.

Extending the annealing period at $750^{\circ} \mathrm{C}$ for 8 hours (sample I-4) resulted in the absence of free, non incorporated tungsten oxide phases and almost total incorporation of W. Indeed, the lattice parameters of the rutile phase $(a=4.690 \AA, c=2.910 \AA)$ are very close to those reported for $\mathrm{Ti}_{0.7} \mathrm{~W}_{0.3} \mathrm{O}_{2}$ mixed oxide in Ref. [19] ( $a=4.683(1) \AA, c=$ 2.919(1) $\AA$ ). In this sample the cation substitution in $\mathrm{TiO}_{2}$ resulted in $\mathrm{Ti}_{0.7} \mathrm{~W}_{0.3} \mathrm{O}_{2}$ composition with rutile/anatase ratio of about 65.5/33 (see Table 2).

The results imply that the role of the HTT is to facilitate tungsten incorporation into the $\mathrm{TiO}_{2}$ particles. The particle size seems to be sensitive for the temperature of the treatment but not for the duration of the annealing, at least above $2 \mathrm{~h}$.

Even if preparation route I followed by $8 \mathrm{~h} 750^{\circ} \mathrm{C}$ heat treatment in $\mathrm{He}$ and reduction for $10 \mathrm{~min}$ at $650^{\circ} \mathrm{C}$ in $\mathrm{H}_{2}$ resulted in good tungsten incorporation, the rutile to anatase ratio, along with the overall crystallinity of the samples (30-35\%) remained inferior. These results indicate that upon using of microwave-assisted solvothermal synthesis the presence of well dispersed amorphous phase or microcrystals of $\mathrm{Ti}_{(1-\mathrm{x})} \mathrm{W}_{\mathrm{x}} \mathrm{O}_{2}$ mixed oxides and/or free, non incorporated tungsten oxide phases $\left(\mathrm{WO}_{3}\right.$, $\mathrm{WO}_{2}$ ) smaller than $4.0 \mathrm{~nm}$ (detection limit for our XRD setup) can not be excluded.

Because of the relatively poor output of synthesis route I, for the preparation of $\mathrm{Ti}_{(1-\mathrm{x})} \mathrm{W}_{\mathrm{x}} \mathrm{O}_{2}-\mathrm{C}$ composite materials the low-temperature sol-gel synthesis route III was preferred. An important variable of synthesis route III is the duration of the room temperature aging of the Ti-sol in the presence of carbon; its effect on the structure of the $\mathrm{Ti}_{0.7} \mathrm{~W}_{0.3} \mathrm{O}_{2}-\mathrm{C}$ composite materials obtained after addition of tungsten precursor is demonstrated in Table 3. Results given in Table 3 indicate that by increasing the length of the aging the rutile/anatase ratio both before and after the multistep heat treatment increased considerably. Similarly, the relative abundance of non incorporated $\mathrm{WO}_{2}$ 
Table 3. Influence of the duration of RT aging of the Ti-sol in the presence of carbon derived from XRD results.

\begin{tabular}{|c|c|c|c|c|c|c|c|c|c|c|}
\hline \multirow[t]{2}{*}{ Samples } & \multirow{2}{*}{$\begin{array}{c}\text { Duration, } \\
\text { days }\end{array}$} & \multicolumn{3}{|c|}{ WHTT $^{\text {a) }}$ (Phase, \%) } & \multicolumn{3}{|c|}{ HTT $^{\text {b) }}$ (Phase, \%) } & \multirow{2}{*}{$\begin{array}{c}\text { Lattice } \\
\text { parameters, }\end{array}$} & \multirow{2}{*}{$\begin{array}{c}\text { W } \\
\text { subst. } \\
\%\end{array}$} & \multirow{2}{*}{$\begin{array}{c}\text { Size }^{\mathrm{d})} \\
\text { (WHTT/HTT), } \\
\text { nm }\end{array}$} \\
\hline & & $\mathbf{R}$ & $\mathbf{A}$ & $\mathbf{W O}_{3} / \mathbf{W O}_{2}$ & $\mathbf{R}$ & $\mathbf{A}$ & $\mathrm{WO}_{3} / \mathbf{W O}_{2}$ & & & \\
\hline III-1 & 0.5 & 10 & 90 & $0 / 0$ & 10 & 50 & $2 / 38$ & $a=4.710, c=2.900$ & $40-45$ & $13 / 25$ \\
\hline III-2 & 1 & 30 & 70 & $0 / 0$ & 50 & 30 & $2 / 18$ & $a=4.710, c=2.900$ & $40-45$ & $18 / 25$ \\
\hline III-3 & 2 & 100 & 0 & $0 / 0$ & 85 & 0 & $0 / 15$ & $a=4.660, c=2.925$ & 25 & $22 / 25$ \\
\hline III-4 & 3 & 100 & 0 & $0 / 0$ & 90 & 0 & $0 / 10$ & $a=4.660, c=2.925$ & 25 & $22 / 25$ \\
\hline III-5 & 4 & 100 & 0 & $0 / 0$ & 92 & 0 & $0 / 8$ & $a=4.670, c=2.920$ & $25-30$ & $22 / 25$ \\
\hline
\end{tabular}

a) WHTT (without high-temperature treatment): the samples were studied before any HTT;

b) HTT: the samples were studied after HTT in He at $750^{\circ} \mathrm{C}$ for $8 \mathrm{~h}$ and reduction in $\mathrm{H}_{2}$ at $650^{\circ} \mathrm{C}$ for $10 \mathrm{~min}$;

c) Lattice parameters of the rutile phase obtained after HTT. Pure rutile $\mathrm{TiO}_{2}: a=4.593 \AA, c=2.959 \AA$

d) Average crystallite size of the rutile phase obtained before /after HTT.

$\mathrm{R}$ : rutile, $\mathrm{A}$ : anatase. Composite $50 \mathrm{Ti}_{0.7} \mathrm{~W}_{0.3} \mathrm{O}_{2}-50 \mathrm{C}$ materials were prepared by using synthesis route III. 
crystallite phase decreased with longer aging time (from 38 to $8 \%$ ). When the aging procedure was short (0.5-1 day) a trace amount of unreduced tungsten $\mathrm{WO}_{3}$ oxide phase was also observed (see samples III-1 and III-2 in Table 3).

After HTT of the samples aged for 2-4 days the average crystallite size of the rutile phase was increased only slightly. As shown in Table 3 the size of the rutile phase crystallites obtained after stirring of the Ti-sol and carbon suspension at RT for 0.5-1 day and studied without any HTT was considerably smaller. However after HTT the difference between the average crystallite sizes of the rutile phase obtained using various duration of aging procedure was not observed.

Data given in Table 3 show that the sample III-5 obtained after 4 days of RT aging can be completely indexed with a tetragonal unit cell that is shifted from pure $\mathrm{TiO}_{2}$ due to doping with tungsten $(a=4.670 \AA, c=2.920 \AA$ ). Based on the XRD results after HTT only route III leads to almost pure rutile phase $\left(\mathrm{R} / \mathrm{A} / \mathrm{WO}_{2}=92 / 0 / 8\right)$ with high crystallinity (98-100\%) and high degree of tungsten incorporation $\left(\mathrm{W}_{\text {subst }}=25-30 \%\right)$. The results underline that the presence of rutile crystallites at the beginning of the HTT process is highly beneficial for efficient tungsten incorporation.

\subsubsection{Microstructure of the $50 \mathrm{Ti}_{0.7} \mathrm{~W}_{0.3} \mathrm{O}_{2}-50 \mathrm{C}$ composite and the related electrocatalysts}

The atomic composition of both the sample III-5 and the individual particles was evaluated by analyzing different regions with EDS (SEM images not shown). EDS measurements indicated a $\mathrm{Ti} / \mathrm{W}$ atomic ratio of $69.3 / 30.7$, which agrees well with the expected atomic ratio of 70/30 for $\mathrm{Ti}_{0.7} \mathrm{~W}_{0.3} \mathrm{O}_{2}$. This suggests that the composition of the $\mathrm{Ti}_{(1-\mathrm{x})} \mathrm{W}_{\mathrm{x}} \mathrm{O}_{2}$ mixed oxides can be successfully controlled by adjusting the ratios of $\mathrm{Ti}$ and $\mathrm{W}$ precursor compounds. It should be remarked that the standard deviation of the compositional analysis between different analyzed regions is ca. $3 \%$, which means that $\mathrm{Ti}$ and $\mathrm{W}$ atoms are homogeneously distributed throughout each analyzed region of the samples. No relevant compositional differences were detected between particles irrespectively of their size. EDS analysis of different regions of the sample reveals the coexistence of $\mathrm{Ti}_{0.7} \mathrm{~W}_{0.3} \mathrm{O}_{2}$ mixed oxide along with the active carbon. Based on the EDS results an average composition in $\mathrm{Ti}_{0.7} \mathrm{~W}_{0.3} \mathrm{O}_{2}-\mathrm{C}$ composite materials was $53.2 \mathrm{wt} \%$ of $\mathrm{Ti}_{0.7} \mathrm{~W}_{0.3} \mathrm{O}_{2}$ and $46.8 \mathrm{wt} \%$ of $\mathrm{C}$, which agrees closely with the expected values. 

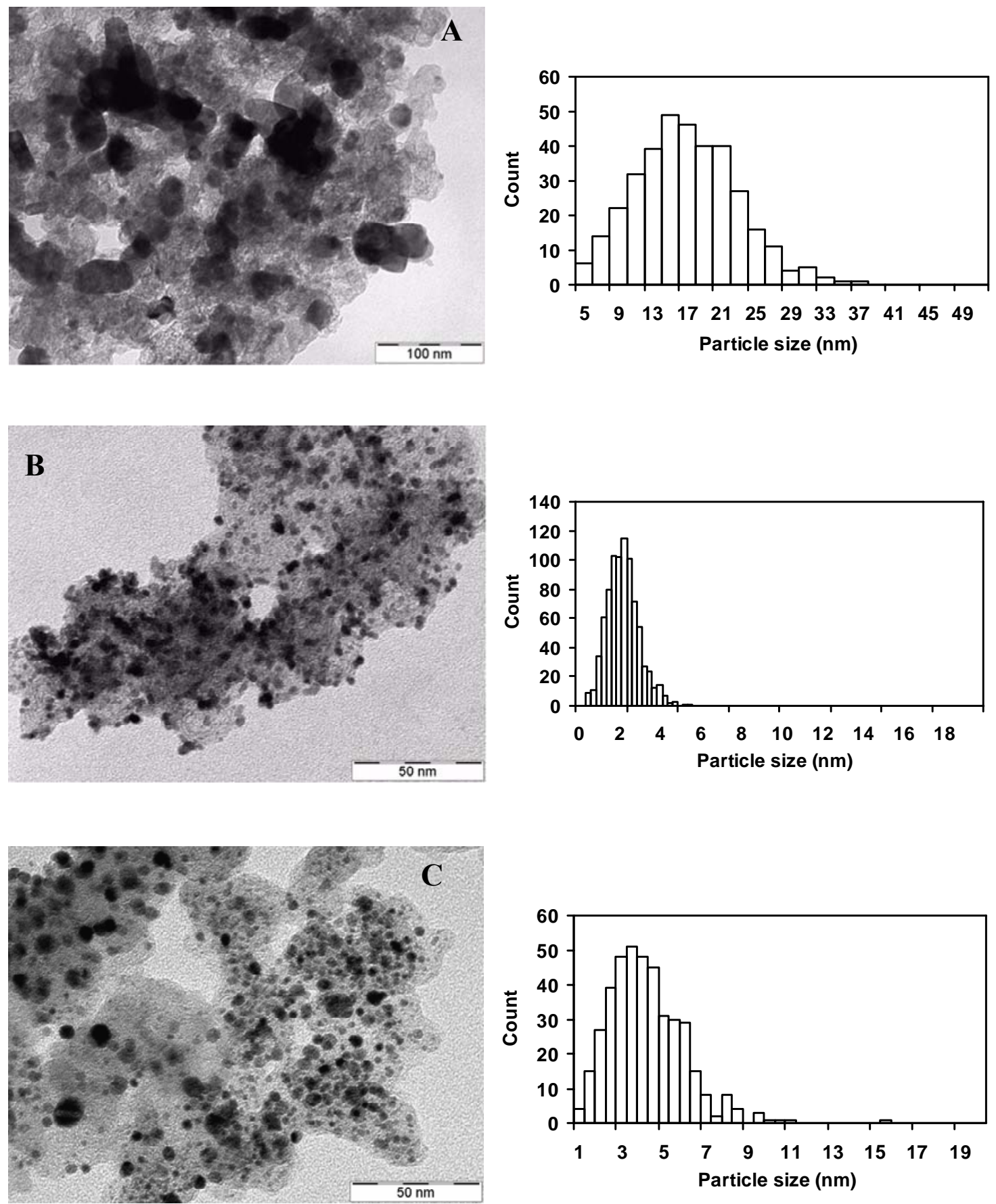

Fig. 3 TEM images and histogram of particle size distribution for (A) $50 \mathrm{Ti}_{0.7} \mathrm{~W}_{0.3} \mathrm{O}_{2}$ 50C support (route III), (B) $\mathrm{Pt} / \mathrm{Ti}_{0.7} \mathrm{~W}_{0.3} \mathrm{O}_{2}-\mathrm{C}$ and (C) $\mathrm{Pt} / \mathrm{C}$ catalysts.

The corresponding $\mathrm{Pt} / \mathrm{Ti}_{0.7} \mathrm{~W}_{0.3} \mathrm{O}_{2}-\mathrm{C}$ anode electrocatalyst prepared by loading of $40 \mathrm{wt} \% \mathrm{Pt}$ via the $\mathrm{NaBH}_{4}$-assisted ethylene-glycol reduction method was also analyzed with EDS. EDS analysis of different regions of the electrocatalyst revealed the uniform 
distribution of the $\mathrm{Pt}$ nanoparticles on $\mathrm{Ti}_{0.7} \mathrm{~W}_{0.3} \mathrm{O}_{2}-\mathrm{C}$ composite materials with an average Pt content of $38.6 \mathrm{wt} \%$. This value agreed well with the calculated $40 \mathrm{wt} \%$ used in the catalysts preparation. Based on the EDS results after Pt loading no relevant changes were observed in the Ti/W atomic ratio or the composition of the $\mathrm{Ti}_{0.7} \mathrm{~W}_{0.3} \mathrm{O}_{2}-\mathrm{C}$ support materials. After Pt deposition the $\mathrm{Ti}_{0.7} \mathrm{~W}_{0.3} \mathrm{O}_{2}-\mathrm{C}$ composite contained $51.0 \mathrm{wt} \%$ of $\mathrm{Ti}_{0.7} \mathrm{~W}_{0.3} \mathrm{O}_{2}$ and $49.0 \mathrm{wt} \%$ of $\mathrm{C}$ and an average $\mathrm{Ti} / \mathrm{W}$ atomic ratio calculated from the analysis of different regions of the sample was 72.3/27.7. Relevant composition differences between big and small particles were not detected.

Fig. 3A-C depicts representative TEM micrographs of the $\mathrm{Ti}_{0.7} \mathrm{~W}_{0.3} \mathrm{O}_{2}-\mathrm{C}$ support material and the corresponding $\mathrm{Pt} / \mathrm{Ti}_{0.7} \mathrm{~W}_{0.3} \mathrm{O}_{2}-\mathrm{C}$ and $\mathrm{Pt} / \mathrm{C}$ anode electrocatalysts along with the corresponding histograms for particle size distribution. TEM images in Fig. 3A reveal that after $\mathrm{HTT}$ in $\mathrm{He}$ at $750^{\circ} \mathrm{C}$ for 8 hours, followed by $\mathrm{H}_{2}$ treatment at $650^{\circ} \mathrm{C}$ $\mathrm{Ti}_{0.7} \mathrm{~W}_{0.3} \mathrm{O}_{2}$-C composite materials consist of agglomerates of primary $\mathrm{Ti}_{0.7} \mathrm{~W}_{0.3} \mathrm{O}_{2}$ particles of $17.9 \pm 6.0 \mathrm{~nm}$ in diameter determined by counting more than 350 particles from different regions of the sample. This value was slightly lower than that of calculated by XRD analysis (see samples III-5 in Table 3). Actually, XRD, accounting for the long range periodicity in crystallites, is not sensitive to small particles $(\leq 2.5$ $\mathrm{nm}$ ). As a consequence, in X-ray diffraction patterns information originated from the larger crystallites dominates over that from the smaller ones leading to an apparent shift of the estimated particle size.

The ability of $\mathrm{TiO}_{2}$ and $\mathrm{Ti}_{(1-\mathrm{x})} \mathrm{W}_{\mathrm{x}} \mathrm{O}_{2}$ primary nanoparticles to agglomerate upon aging and any heat treatment has been demonstrated in Refs. [15,16,24,31,33]. Because of the difficulties in the precise measurement of the size of the primary particles included in the agglomerates, the main particle size of agglomerates was also estimated $(31.8 \pm 13.4 \mathrm{~nm})$.

After HTT in $\mathrm{He}$ at $750^{\circ} \mathrm{C}$ for 8 hours the BET surface area of this sample was about $\mathrm{S}_{\mathrm{BET}}=640 \mathrm{~m}^{2} \mathrm{~g}^{-1}$. High value of the BET surface area obtained after HTT demonstrates that in the presence of activated carbon the particles of the composite materials are successfully protected from sintering.

The uniform distribution of $\mathrm{Pt}$ in the $\mathrm{Pt} / \mathrm{Ti}_{0.7} \mathrm{~W}_{0.3} \mathrm{O}_{2}-\mathrm{C}$ anode electrocatalyst was verified via TEM imaging (see Fig. 3B). TEM micrographs show highly dispersed spherical Pt particles with main particle size of $2.3 \pm 0.8 \mathrm{~nm}$. The particle size distribution of the $\mathrm{Pt} / \mathrm{C}$ catalyst prepared by the $\mathrm{NaBH}_{4}$-assisted $\mathrm{EG}$ reduction method is also given for comparison (see Fig. 3C). For the Pt/C catalyst platinum particles of $4.5 \pm$ 
$1.8 \mathrm{~nm}$ in diameter were determined by counting more than 400 particles from different regions of the sample. The stabilizing ability of $\mathrm{TiO}_{2}$ used as a support for Pt is well reported in the literature. It has been shown [69] that the role of $\mathrm{TiO}_{2}$ is (i) to avoid the agglomeration of Pt particles, (ii) to help in controlling the nanostructure of the catalyst and (iii) to provide thermal and redox stability.

\subsubsection{XPS analysis of the mixed oxide materials}

As it was delineated in the preceding sections, we expect a marked change of the chemical state of tungsten by the end of the multistep heat treatment process. In order to confirm this expectation, XPS experiments were performed on both carbon-free $\mathrm{Ti}_{0.7} \mathrm{~W}_{0.3} \mathrm{O}_{2}$ samples and $\mathrm{Ti}_{0.7} \mathrm{~W}_{0.3} \mathrm{O}_{2}-\mathrm{C}$ composites.

As tungsten may occur in numerous chemical states ranging from metal to $\mathrm{W}^{6+}$, generally spectrum modeling is needed to facilitate the interpretation of the often complex W $4 \mathrm{f}$ envelopes. Before discussing our XPS data, it is appropriate to shortly summarize the knowledge establishing the assignment of the observed spectral features.

The $\mathrm{W} 4 \mathrm{f}$ core level spectrum of $\mathrm{W}^{6+}$ from $\mathrm{WO}_{3}$-like environments is

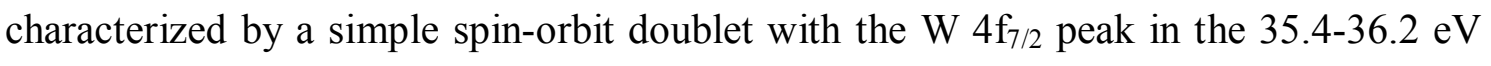
binding energy range [51,70-72]. The peak separation is reported to be 2.1-2.2 eV. Typically the spectra of more reduced $\mathrm{W}$ species are also approached by simple doublets shifted to lower binding energies. On this basis, the $4 \mathrm{f}_{7 / 2}$ component from $\mathrm{W}^{5+}$ is reported to appear in the range of 34.4-35.0 eV [71,73], although it is claimed to be less stable than $\mathrm{W}^{6+}$ or $\mathrm{W}^{4+}$. $\mathrm{A} 4 \mathrm{f}_{7 / 2}$ peak around $32.0 \mathrm{eV}$ is attributed to $\mathrm{W}^{2+}$ [71-72], while metallic tungsten signals emerge at 31.2-31.4 eV [70-71]. On the other hand, in the case of $\mathrm{W}^{4+}$ in a conducting oxide environment a compound peak shape consisting of spin-orbit doublets of a main peak and a satellite was suggested [74-75], as a result of co-existence of two fundamentally differently screened final states. The $4 \mathrm{f}_{7 / 2}$ peak of $\mathrm{W}^{4+}$ appears around 32.8-34.0 eV [70-71,74]. The air-exposed surface of $\mathrm{WO}_{2}$ is reported to be covered by a $\mathrm{WO}_{3}$ layer $[70,73]$.

Accordingly, the $\mathrm{W} 4 \mathrm{f}$ spectra of the investigated $\mathrm{Ti}_{0.7} \mathrm{~W}_{0.3} \mathrm{O}_{2}$ samples were modeled by spin-orbit doublets for the $\mathrm{W}^{6+}$ and $\mathrm{W}^{5+}$ states; the peak shapes were derived from the reference spectra of $\mathrm{WO}_{3}$. In order to obtain a peak shape for $\mathrm{W}^{4+}$ states, the surface oxide from a $\mathrm{WO}_{2}$ powder was removed by annealing in vacuum up to $600^{\circ} \mathrm{C}$, until no further changes were seen in the $\mathrm{W} 4 \mathrm{f}$ spectrum. In addition, as the $\mathrm{Ti}$ $3 \mathrm{p}$ band of $\mathrm{TiO}_{2}$ around $37.5 \mathrm{eV}$ exactly overlaps with the $\mathrm{W} 4 \mathrm{f}$ region, its contribution 
Table 4. Results of the compositional and chemical state analysis of the $\mathrm{Ti}_{0.7} \mathrm{~W}_{0.3} \mathrm{O}_{2}$ samples (route II) and the reduced $50 \mathrm{Ti}_{0.7} \mathrm{~W}_{0.3} \mathrm{O}_{2}-50 \mathrm{C}$ composite (route III) by XPS. The characteristic binding energy and relative contribution of the identified chemical states are shown.

\begin{tabular}{|c|c|c|c|c|c|c|}
\hline Sample & $\begin{array}{c}\mathrm{W} 4 \mathrm{f}_{7 / 2} \\
\mathrm{BE}(\mathrm{eV})\end{array}$ & $\begin{array}{c}\text { Ti } 2 p_{3 / 2} \\
\text { BE }(e V)\end{array}$ & $\begin{array}{c}\mathrm{O} 1 \mathrm{~s} \\
\mathrm{BE}(\mathrm{eV})\end{array}$ & $\begin{array}{c}\text { C 1s } \\
\text { BE }(e V)\end{array}$ & $\begin{array}{l}\mathrm{Ti} / \mathrm{W} \\
\text { (at/at) }\end{array}$ & $\begin{array}{l}\mathrm{Ti}(\mathrm{W}) \mathrm{O}_{\mathrm{x}} / \mathrm{C} \\
(\mathrm{wt} \% / \mathrm{wt} \%)\end{array}$ \\
\hline $\mathrm{WO}_{3}$ & $35.9(100 \%) \mathrm{W}^{6+}$ & n.a. & $\begin{array}{l}531.0 \mathrm{WO}_{\mathrm{x}} \\
533.5 \mathrm{H}_{2} \mathrm{O}\end{array}$ & $285.0 \mathrm{CH}_{\mathrm{x}}$ & n.a. & n.a. \\
\hline $\mathrm{WO}_{2}{ }^{\mathrm{a})}$ & $\begin{array}{l}35.9(26 \%) \mathrm{W}^{6+} \\
34.9(17 \%) \mathrm{W}^{5+} \\
32.6(57 \%) \mathrm{W}^{4+}\end{array}$ & n.a. & $\begin{array}{c}530.8 \mathrm{WO}_{\mathrm{x}} \\
532.6-\mathrm{OH}, \mathrm{CO}_{\mathrm{x}}\end{array}$ & $284.9 \mathrm{CH}_{\mathrm{x}}$ & n.a. & n.a. \\
\hline $\mathrm{Ti}_{0.7} \mathrm{~W}_{0.3} \mathrm{O}_{2}(\mathrm{WR})^{\mathrm{b})}$ & $\begin{array}{l}36.0(63 \%) \mathrm{W}^{6+} \\
35.2(22 \%) \mathrm{W}^{5+} \\
33.8(15 \%) \mathrm{W}^{4+}\end{array}$ & $459.3(100 \%) \mathrm{Ti}^{4+}$ & $\begin{array}{c}530.8 \mathrm{WO}_{\mathrm{x}}\left(\mathrm{TiO}_{\mathrm{x}}\right) \\
532.0-\mathrm{OH}, \mathrm{CO}_{\mathrm{x}}\end{array}$ & $284.7 \mathrm{CH}_{\mathrm{x}}$ & $1.7: 1$ & n.a. \\
\hline $\mathrm{Ti}_{0.7} \mathrm{~W}_{0.3} \mathrm{O}_{2}(\mathrm{R})^{\mathrm{c})}$ & $\begin{array}{c}36.0(50 \%) \mathrm{W}^{6+} \\
34.7(9 \%) \mathrm{W}^{5+} \\
33.4(41 \%) \mathrm{W}^{4+}\end{array}$ & $\begin{array}{c}459.4(95 \%) \mathrm{Ti}^{4+} \\
457.2(5 \%) \mathrm{Ti}^{3+}\end{array}$ & $\begin{array}{c}530.8 \mathrm{WO}_{\mathrm{x}}\left(\mathrm{TiO}_{\mathrm{x}}\right) \\
531.9-\mathrm{OH}, \mathrm{CO}_{\mathrm{x}} \\
533.1 \mathrm{H}_{2} \mathrm{O}\end{array}$ & $\begin{array}{l}284.8 \mathrm{CH}_{\mathrm{x}} \\
286.5-\mathrm{C}-\mathrm{O} \\
289.4 \mathrm{CO}_{3} \\
\end{array}$ & $2: 1$ & n.a. \\
\hline $50 \mathrm{Ti}_{0.7} \mathrm{~W}_{0.3} \mathrm{O}_{2}-50 \mathrm{C}$ & $\begin{array}{l}35.9(35 \%) \mathrm{W}^{6+} \\
34.8(19 \%) \mathrm{W}^{5+} \\
33.3(46 \%) \mathrm{W}^{4+}\end{array}$ & $\begin{array}{l}459.2(92 \%) \mathrm{Ti}^{4+} \\
457.4(8 \%) \mathrm{Ti}^{3+}\end{array}$ & $\begin{array}{c}530.8 \mathrm{WO}_{\mathrm{x}}\left(\mathrm{TiO}_{\mathrm{x}}\right) \\
532.8-\mathrm{OH}, \mathrm{CO}_{\mathrm{x}}\end{array}$ & $\begin{array}{c}\text { 284.4 Graphitic C } \\
289.7-\mathrm{COOH}, \\
-\mathrm{OCO}_{2}\end{array}$ & $2.2: 1$ & $48: 52$ \\
\hline
\end{tabular}

${ }^{\text {a) }}$ Unannealed state (surface oxidized to $\mathrm{W}^{6+}$ );

b) WR (without reduction): the sample was studied after $\mathrm{HTT}$ in $\mathrm{He}$ at $750^{\circ} \mathrm{C}$ for $8 \mathrm{~h}$ and before reduction in $\mathrm{H}_{2}$;

${ }^{\text {c) }} \mathrm{R}$ (reduced): the sample was studied after $\mathrm{HTT}$ in $\mathrm{He}$ at $750^{\circ} \mathrm{C}$ for $8 \mathrm{~h}$ and reduction in $\mathrm{H}_{2}$ at $650^{\circ} \mathrm{C}$ for $10 \mathrm{~min}$. 
was subtracted using the $\mathrm{Ti} 3 \mathrm{p} / \mathrm{Ti} 2 \mathrm{p}$ intensity ratio measured on a Degussa P25 reference sample. No lower oxidation state than $\mathrm{W}^{4+}$ was observed in the investigated samples. Compositional as well as chemical state data derived from the core level spectra of the samples is summarized in Table 4.

Fig. 4A compares the $\mathrm{W} 4 \mathrm{f}$ spectra of a non-reduced or a $650^{\circ} \mathrm{C} 10 \mathrm{~min}$ reduced carbon-free $\mathrm{Ti}_{0.7} \mathrm{~W}_{0.3} \mathrm{O}_{2}$ sample prepared by synthesis route II with that of a reduced $\mathrm{Ti}_{0.7} \mathrm{~W}_{0.3} \mathrm{O}_{2}$-C composite sample from synthesis route III. XRD revealed complete $\mathrm{W}$ incorporation in both reduced samples, while substantial phase separation was seen for the non-reduced system. In addition, reference spectra for $\mathrm{WO}_{3}\left(\mathrm{~W}^{6+}\right)$ and $\mathrm{WO}_{2}\left(\mathrm{~W}^{4+}\right)$ are also shown.
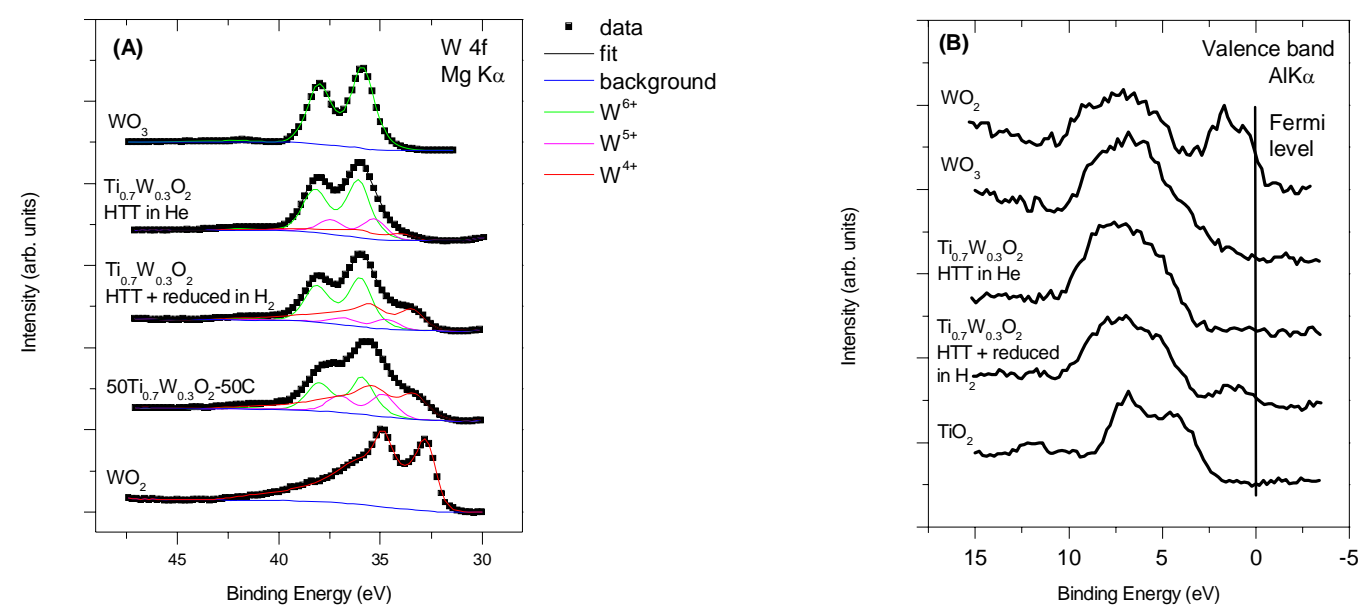

Fig. 4 (A): W $4 \mathrm{f}$ core level spectra of the non-reduced and the reduced carbon-free $\mathrm{Ti}_{0.7} \mathrm{~W}_{0.3} \mathrm{O}_{2}$ samples (route II), and the reduced $50 \mathrm{Ti}_{0.7} \mathrm{~W}_{0.3} \mathrm{O}_{2}-50 \mathrm{C}$ composite (route III) along with reference spectra of $\mathrm{WO}_{3}$ and $\mathrm{WO}_{2}$. (B): valence band spectra of the nonreduced and the reduced carbon-free $\mathrm{Ti}_{0.7} \mathrm{~W}_{0.3} \mathrm{O}_{2}$ samples compared with the spectra of $\mathrm{WO}_{2}, \mathrm{WO}_{3}$ and $\mathrm{TiO}_{2}$.

The $\mathrm{W}$ 4f region of the non-reduced $\mathrm{Ti}_{0.7} \mathrm{~W}_{0.3} \mathrm{O}_{2}$ sample contains essentially $\mathrm{W}^{6+}$ and $\mathrm{W}^{5+}$ contributions with a minor $\mathrm{W}^{4+}$ signal. While the $\mathrm{W}^{6+}$ and $\mathrm{W}^{5+}$ doublets appear more or less in the expected binding energy range, a substantial shift towards higher energies was seen for $\mathrm{W}^{4+}$ when compared to the reference spectrum. The fraction of $\mathrm{W}$ in the metal ion content of the sample is somewhat higher than the expected value, 
which suggests some surface segregation of tungsten. Ti is in its fully oxidized state as judged from the $459.3 \mathrm{eV}$ binding energy of the Ti $2 \mathrm{p}_{3 / 2}$ peak. It may be worth to note that in Ti-W mixed oxide systems the Ti $2 \mathrm{p}_{3 / 2}$ binding energy is typically slightly larger than in pure $\mathrm{TiO}_{2}$ [45], the latter being around $458.8 \mathrm{eV}$.

The overall shape of the $\mathrm{W} 4 \mathrm{f}$ region of the reduced $\mathrm{Ti}_{0.7} \mathrm{~W}_{0.3} \mathrm{O}_{2}$ sample is qualitatively similar to that of surface oxidized $\mathrm{WO}_{2}$ [70,73]. Spectrum synthesis confirms the presence of $\mathrm{W}^{6+}\left(50 \%\right.$, at $36.0 \mathrm{eV}$ binding energy) and $\mathrm{W}^{4+}(41 \%$, at 33.4 $\mathrm{eV})$ ionic states, along with a small amount of $\mathrm{W}^{5+}(9 \%$, at $34.7 \mathrm{eV})$. The leading component of the $\mathrm{W}^{4+}$ envelope is still at a higher binding energy than in $\mathrm{WO}_{2}$ which is reasonable if the differences between the local tungsten environment in the two cases are considered. The ratio of $\mathrm{W}$ with respect to the total metal content decreased to $33 \%$, supposedly pointing to a better incorporation of $\mathrm{W}$ into the titania particles. Along with the considerable reduction of $\mathrm{W}$, a minute reduction of $\mathrm{Ti}$ is also evident from the appearance of a lower binding energy $\mathrm{Ti} 2 \mathrm{p}_{3 / 2}$ component $\left(457.2 \mathrm{eV}, \mathrm{Ti}^{3+}\right)$ besides the $\mathrm{Ti}^{4+}$ signal at $459.4 \mathrm{eV}$.

The reduced $\mathrm{Ti}_{0.7} \mathrm{~W}_{0.3} \mathrm{O}_{2}-\mathrm{C}$ sample exhibits a qualitatively similar $\mathrm{W} 4 \mathrm{f}$ region. While the significant $\mathrm{W}^{6+}$ and $\mathrm{W}^{5+}$ intensity is probably the result of the air exposure following the reduction, the dominant contribution still arises from $\mathrm{W}^{4+}$ ionic states. In this sample Ti retains its fully oxidized state.

The conclusions from the XPS data are in agreement with the XRD observations. In the sample with little $\mathrm{W}$ incorporation (non-reduced $\mathrm{Ti}_{0.7} \mathrm{~W}_{0.3} \mathrm{O}_{2}$ ) mostly highly oxidized tungsten species are seen, while in the systems with high level of substitutional tungsten incorporation high concentration of $\mathrm{W}^{4+}$ is seen, in spite of the air exposure. The similar nature of the two reduced systems demonstrates the success of the synthesis by route III even in the presence of carbon.

In Fig. 4B the valence band XPS spectra of the non-reduced and the reduced carbon-free $\mathrm{Ti}_{0.7} \mathrm{~W}_{0.3} \mathrm{O}_{2}$ samples are compared with the spectra of $\mathrm{TiO}_{2}, \mathrm{WO}_{3}$ and $\mathrm{WO}_{2}$. The wide band gap nature of $\mathrm{TiO}_{2}$ and $\mathrm{WO}_{3}$ is evident from the lack of any notable emission above the $\mathrm{O} 2 \mathrm{p}$-derived valence band edge. The spectrum of $\mathrm{WO}_{2}$ exhibits a strong band at the Fermi energy, in accordance with its metallic nature [70,73,75-76]. No emission was found in the non-reduced $\mathrm{Ti}_{0.7} \mathrm{~W}_{0.3} \mathrm{O}_{2}$ sample at the Fermi energy, while in the reduced case a clear peak appears in this spectral region, confirming that the presence of $\mathrm{W}^{4+}$ species indeed results in a metallic-like electronic structure in the mixed oxide. 
The data confirm that the high temperature treatment in inert atmosphere leads to the formation of a semiconducting material. Enhanced tungsten incorporation and activation is achieved by a short reduction, which transforms the material into a metallic state. Although surface oxidation upon air exposure is evident, similarly to the case of $\mathrm{WO}_{2}$, the mixed oxide material is stable enough to retain some of its metallicity. Carbon-supported systems are less suitable for valence band investigations, as carbon originated signals extend up to the Fermi level.

\subsection{Electrochemical performance}

Fig. 5 compares the cyclic voltammogramms (CVs) and Ar-purged CO-stripping curves recorded on the $\mathrm{Pt} / \mathrm{Ti}_{0.7} \mathrm{~W}_{0.3} \mathrm{O}_{2}$ - $\mathrm{C}$ composite supported samples with those obtained on unmodified parent $\mathrm{Pt} / \mathrm{C}$ and $\mathrm{Pt} / \mathrm{Ti}_{0.7} \mathrm{~W}_{0.3} \mathrm{O}_{2}$ (with $20 \mathrm{wt} \% \mathrm{C}$ added) catalysts. For comparison our results obtained on the PtRu/C (Quintech) with $\mathrm{Pt}=20$ $\mathrm{wt} \%$, considered as the state-of-the art CO-tolerant electrocatalyst, were also included (see Fig. 5b).

As seen from Fig. 5 all catalysts studied show a typical CV of $\mathrm{Pt}$ with the classical features of the under-potentially deposited hydrogen $\left(\mathrm{H}_{\text {upd }}\right)$ adsorption/desorption between $0.05<\mathrm{E}<0.40 \mathrm{~V}$. It is necessary to mention that with exception of the $\mathrm{Pt} / \mathrm{C}$ catalyst (Fig. 5a) a pronounced contribution of double layer charging/discharging was observed. In Refs. $[2,6,8,77]$ these features were related to the redox reaction of tungsten oxides, such as $\mathrm{WO}_{3} / \mathrm{WO}_{2}$. As shown in Fig. 5a-c the features typical for underpotential deposition of hydrogen are clearly resolved at 135 $\mathrm{mV}$ and $245 \mathrm{mV}$. On the electrocatalysts prepared using composite materials synthesized by route I (Fig. 5d) and III (Fig. 5f) slight shift of the second peak (255 $\mathrm{mV}$ ) and higher Coulombic charge of the hydrogen region was observed. In Ref. [9] peaks at $0.13 \mathrm{~V}$ and $0.27 \mathrm{~V}$ (vs. RHE) were attributed to hydrogen adsorption/desorption on/from Pt (110) and (100) facets, respectively. Based on the similarity of the peak positions observed on $\mathrm{Pt}-\mathrm{WO}_{\mathrm{x}} / \mathrm{C}$ and reference $\mathrm{Pt} / \mathrm{C}$ catalysts it has been suggested in Ref. [9] that $\mathrm{WO}_{\mathrm{x}}$ only slightly modifies the electronic density of the Pt nanoparticles supported on active carbon.

It is clearly seen from Fig. $5 \mathrm{c}$ and $5 \mathrm{e}$ that the $\mathrm{H}_{\text {upd }}$ areas are quite similar for $\mathrm{Pt} / \mathrm{Ti}_{0.7} \mathrm{~W}_{0.3} \mathrm{O}_{2}$ catalyst and the $\mathrm{Pt} / 50 \mathrm{Ti}_{0.7} \mathrm{~W}_{0.3} \mathrm{O}_{2}-50 \mathrm{C}$ sample prepared by route II with segregated anatase- $\mathrm{TiO}_{2}$ and $\mathrm{WO}_{2}$ phases. As shown in Fig. 5d-f, the Coulombic charge of the hydrogen region for the electrocatalysts prepared using $\mathrm{Ti}_{0.7} \mathrm{~W}_{0.3} \mathrm{O}_{2}-\mathrm{C}$ composite 


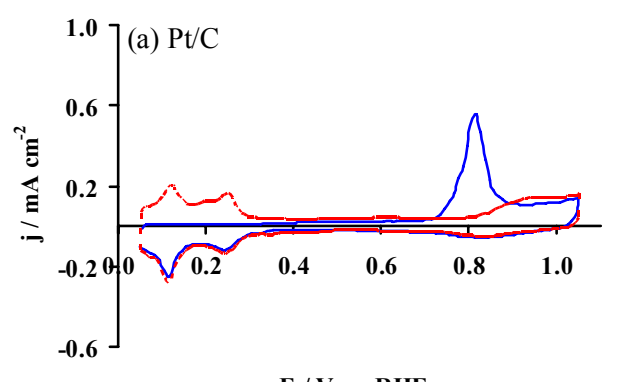

E / V vs. RHE

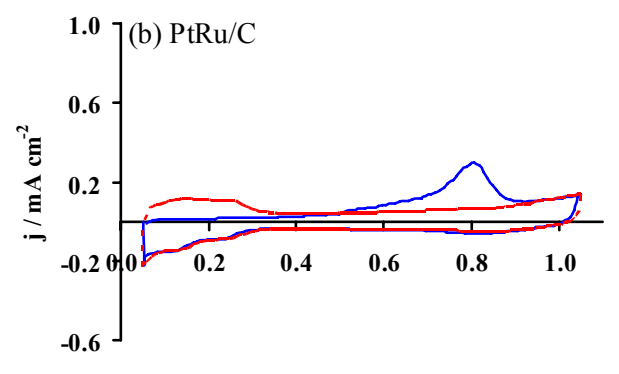

E / V vs. RHE

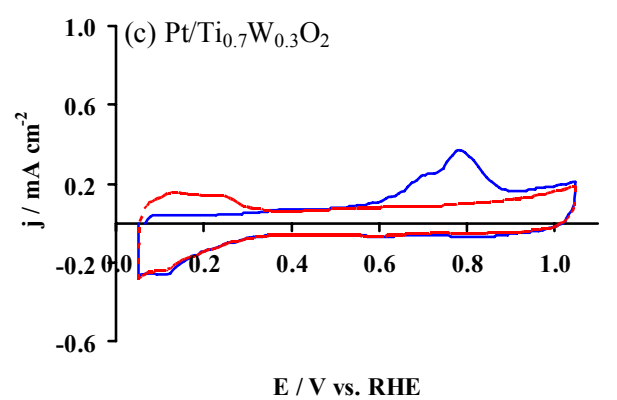

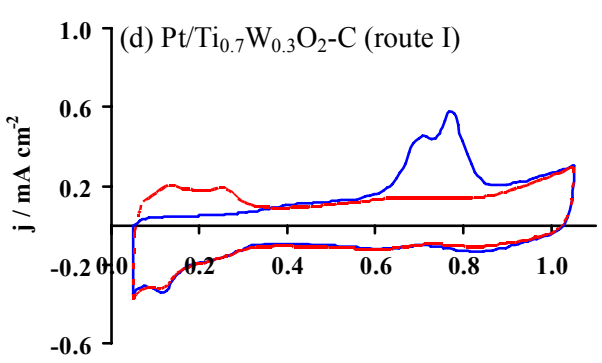

E / V vs. RHE

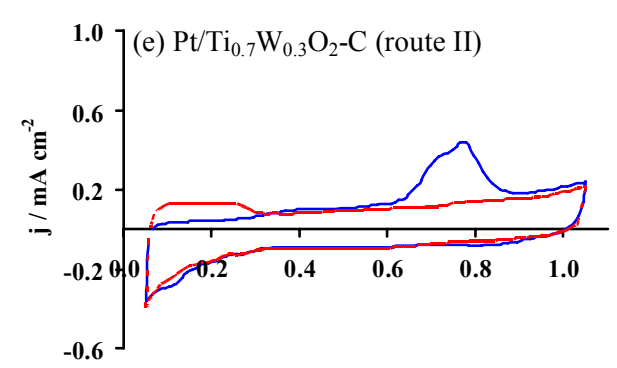

E / V vs. RHE

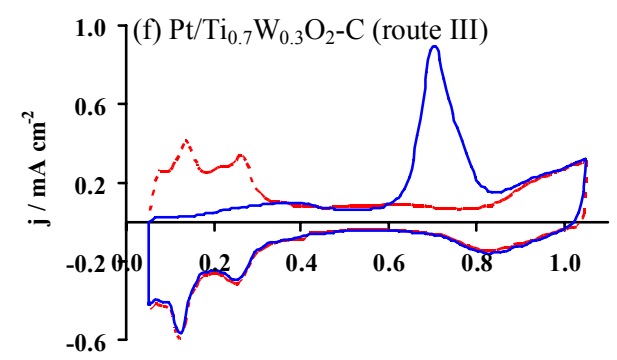

E / V vs. RHE

Fig. 5 Base cyclic voltammogram (dotted red lines) and $\mathrm{CO}_{\mathrm{ads}}$ stripping voltammogram after Ar purging (solid blue lines) on (a) $\mathrm{Pt} / \mathrm{C}$, (b) $\mathrm{PtRu} / \mathrm{C}$, (c) $\mathrm{Pt} / \mathrm{Ti}_{0.7} \mathrm{~W}_{0.3} \mathrm{O}_{2}$ (with 20 wt.\% $\mathrm{C}$ added to prepare the ink), (d) $\mathrm{Pt} / \mathrm{Ti}_{0.7} \mathrm{~W}_{0.3} \mathrm{O}_{2}-\mathrm{C}$ (route I), (e) $\mathrm{Pt} / \mathrm{Ti}_{0.7} \mathrm{~W}_{0.3} \mathrm{O}_{2}-\mathrm{C}$ (route II) and (f) $\mathrm{Pt} / \mathrm{Ti}_{0.7} \mathrm{~W}_{0.3} \mathrm{O}_{2}-\mathrm{C}$ (route III) catalysts. Recorded in $0.5 \mathrm{M} \mathrm{H}_{2} \mathrm{SO}_{4}$ at 10 $\mathrm{mV} \cdot \mathrm{s}^{-1}, \mathrm{~T}=25{ }^{\circ} \mathrm{C}$. The current density $\mathbf{j}$ was normalized to the geometrical surface area.

materials increases parallel with the increasing of the degree of $\mathrm{W}$ incorporation into rutile- $\mathrm{TiO}_{2}$ lattice in the following order Route $\mathrm{II}<\mathrm{I}<\mathrm{III}$. This behaviour can be attributed to better protection of Pt nanoparticles from agglomeration on the composite support with high degree of tungsten incorporation. However, in accordance with literature data for $\mathrm{Pt} / \mathrm{WO}_{\mathrm{x}}$ electrocatalysts $[9,77]$ the $\mathrm{H}$ insertion/deinsertion into the $\mathrm{WO}_{\mathrm{x}}$ support, which results in formation of tungsten bronzes $\mathrm{H}_{\mathrm{y}} \mathrm{WO}_{3}$ at low electrode 
potential [78], can also influence (if indeed occurs) the Coulombic charge of the hydrogen region. It is known that the formation of tungsten bronzes is catalyzed by the presence of $\mathrm{Pt}$ because adsorbed $\mathrm{H}$ spills over from the Pt sites to the $\mathrm{WO}_{\mathrm{x}}$ support.

In good agreement with literature $[9,77]$, our results suggest that $\mathrm{Ti}_{0.7} \mathrm{~W}_{0.3} \mathrm{O}_{2}-\mathrm{C}$ composite materials only slightly modify the electronic density of the Pt nanoparticles. Upon using of the composite support prepared by route III, more effective protection of Pt nanoparticles from agglomeration can be reached.

The $\mathrm{CO}_{\text {ads }}$ stripping voltammogram on $\mathrm{Pt} / \mathrm{C}$ (see Fig. 5a) shows the absence of $\mathrm{H}$ desorption peaks (adsorbed $\mathrm{CO}$ blocks the $\mathrm{Pt}$ catalytic sites) and the main $\mathrm{CO}_{\mathrm{ads}}$ stripping peak is located at ca. $820 \mathrm{mV}$. The $\mathrm{CO}_{\text {ads }}$ stripping peak resembles that commonly observed in the literature $[8,77]$.

As can be seen from the $\mathrm{CO}_{\mathrm{ads}}$ stripping curves (see Figs. 5d-f) on all $\mathrm{Pt} / \mathrm{Ti}_{0.7} \mathrm{~W}_{0.3} \mathrm{O}_{2}-\mathrm{C}$ samples larger currents of the hydrogen region between $0.05-0.40 \mathrm{~V}$ and a negative shift of both the onset and peak potentials compared to $\mathrm{Pt} / \mathrm{C}$ were observed. During the first cycle after CO admission on the catalyst supported on the composite material prepared by Route III (see Fig. 5f and Fig. 6a) a "pre-peak" located between 150 and $540 \mathrm{mV}$ and a narrow main peak at $710 \mathrm{mV}$ were found. On samples prepared by Routes I and II (Fig. 5d and 5e, respectively) the "pre-peak" appeared between $\sim 240$ and $\sim 550 \mathrm{mV}$ followed by two $\mathrm{CO}_{\text {ads }}$ electrooxidation peaks at 710 and $780 \mathrm{mV}$. As shown in Fig. 5c similar position of the peaks were obtained on the $\mathrm{Pt} / \mathrm{Ti}_{0.7} \mathrm{~W}_{0.3} \mathrm{O}_{2}$ catalyst (with $20 \mathrm{wt} \% \mathrm{C}$ added).

(a) Ar-purged CO stripping

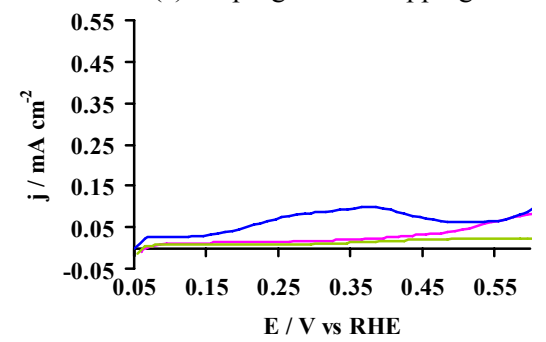

(b) $\mathrm{H}_{2}$-purged CO stripping

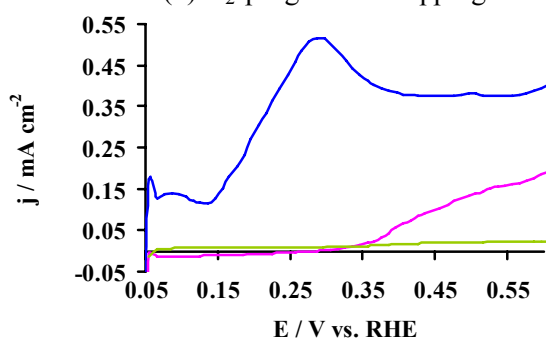

Fig. $6 \mathrm{CO}_{\text {ads }}$ stripping voltammogram after Ar purging (a) and $\mathrm{H}_{2}$ purging (b) in the "pre-peak" potential range between 0.05 and $0.60 \mathrm{~V}$ on Pt/C (green line), PtRu/C (pink line) and $\mathrm{Pt} / \mathrm{Ti}_{0.7} \mathrm{~W}_{0.3} \mathrm{O}_{2}-\mathrm{C}$ (route III, blue line) catalysts. Recorded in $0.5 \mathrm{M} \mathrm{H}_{2} \mathrm{SO}_{4}$ at $10 \mathrm{mV} \cdot \mathrm{s}^{-1}, \mathrm{~T}=25^{\circ} \mathrm{C}$. The current density $\mathbf{j}$ was normalized to the geometrical surface area. 
It is necessary to mention that the Ar-purged $\mathrm{CO}_{\mathrm{ads}}$ stripping voltammograms obtained for catalysts presented in this paper resemble those commonly observed in the literature for CO tolerant W-modified Pt catalysts [1,2,8,77,78]. The "pre-peak" is a characteristic feature for W-containing electrocatalysts [1], which in Refs. [2,6,8,77] was associated with the formation of substoichiometric tungsten oxides $\mathrm{WO}_{3-\mathrm{x}}$. As suggested in Refs. $[8,9,77]$ on $\mathrm{Pt} / \mathrm{WO}_{\mathrm{x}}$ and $\mathrm{Pt}-\mathrm{WO}_{\mathrm{x}} / \mathrm{C}$ catalysts this behaviour can be attributed not only to the deinsertion of protons from the tungsten bronzes $\mathrm{H}_{\mathrm{x}} \mathrm{WO}_{3}$ but may also signal the partial oxidation of the $\mathrm{CO}_{\text {ads }}$ monolayer on Pt. In Ref. [9] Maillard et al. proposed that the sweep rate dependence $\left(v=0.02 \mathrm{~V} \mathrm{~s}^{-1}\right)$ of the electrical charge below the pre-peak at $0.55 \mathrm{~V}$ can be associated to the electrooxidation of $\mathrm{CO}_{\text {ads }}$ on $\mathrm{Pt}$ sites at the interface with the $\mathrm{WO}_{\mathrm{x}} / \mathrm{C}$ support. According to Micoud et al. [77] W-OH groups formed upon $\mathrm{H}^{+}$insertion at low electrode potentials were claimed to be responsible for the high tolerance to $\mathrm{CO}$ of $\mathrm{Pt} / \mathrm{WO}_{\mathrm{x}}$ nanoparticles.

As shown in Figs. 5d and 5e, in case of the support materials with no (route II) and partial $\mathrm{W}$ incorporation into the titania lattice (route $\mathrm{I}$ ) two $\mathrm{CO}_{\mathrm{ads}}$ electrooxidation peaks at about 710 and $780 \mathrm{mV}$ were observed. Similar position of peaks at 760 and 840 $\mathrm{mV}$ was presented in Ref. [9] for $\mathrm{CO}_{\mathrm{ads}}$ electrooxidation on $\mathrm{Pt}-\mathrm{WO}_{\mathrm{x}} / \mathrm{C}$ catalysts. The presence of two electrooxidation peaks was ascribed by Maillard et al. [9,79] to the CO oxidation on Pt nanoparticles with different structures (for example, due to the agglomeration of Pt nanoparticles and formation of nano-grained structures with high surface defect density). However, the presence of two $\mathrm{CO}_{\mathrm{ads}}$ electrooxidation peaks can also be considered from the viewpoint of the degree of the interaction between the $\mathrm{Pt}$ nanoparticles and the $\mathrm{Ti}_{(1-\mathrm{x})} \mathrm{W}_{\mathrm{x}} \mathrm{O}_{2} / \mathrm{C}$ and/or $\mathrm{WO}_{\mathrm{x}} / \mathrm{C}$ underlying layer. Based on the literature results [9] it has been proposed that better $\mathrm{CO}_{\mathrm{ads}}$ tolerance can be achieved when the interaction between $\mathrm{Pt}$ and $\mathrm{WO}_{\mathrm{x}} / \mathrm{C}$ materials is maximised ( $\mathrm{Pt}$ metal perfectly wets the support). In this respect the peak at $780 \mathrm{mV}$ can be attributed to $\mathrm{Pt}$ nanoparticles, which are only slightly influenced by the $\mathrm{WO}_{\mathrm{x}}$-modified composite materials. A peak shifted $70 \mathrm{mV}$ negative versus the peak at $780 \mathrm{mV}$ can be assigned to $\mathrm{CO}_{\mathrm{ads}}$ electrooxidation on $\mathrm{Pt}$ sites at the interface with $\mathrm{WO}_{\mathrm{x}}$-modified composite.

Multiple peaks in CO stripping voltammogramms may be ascribed to the inhomogeneity of the samples prepared by routes I and II (poor crystallinity, the presence of free, non incorporated crystalline and amorphous $\mathrm{WO}_{2}$ phases, segregation of $\mathrm{TiO}_{2}$ and $\mathrm{WO}_{2}$ phases). As seen from Fig. 5 the position of the $\mathrm{CO}_{\text {ads }}$ stripping peak 
at $780 \mathrm{mV}$ (vs. RHE) observed on these samples is close to that observed for $\mathrm{Pt}$ nanoparticles supported on activated carbon. This behaviour may be attributed to imperfect covering of carbon particles with $\mathrm{Ti}_{(1-\mathrm{x})} \mathrm{W}_{\mathrm{x}} \mathrm{O}_{2}$ mixed oxides and/or $\mathrm{W}$ oxides aforementioned for the composite materials prepared by using route I and II.

In case of the sample prepared by route III the position of the main oxidation peak observed at about $710 \mathrm{mV}$ was shifted towards negative potentials by $110 \mathrm{mV}$ with respect to the peak at $820 \mathrm{mV}$ observed on the $\mathrm{Pt} / \mathrm{C}$ catalyst demonstrating an enhanced tolerance to $\mathrm{CO}$ in this composite system, similarly to what was found in the literature for $\mathrm{Pt} / \mathrm{WO}_{\mathrm{x}}$ and $\mathrm{Pt}-\mathrm{WO}_{\mathrm{x}} / \mathrm{C}$ catalysts $[2,8,77,80]$. It has been proposed in Ref. [1] for $\mathrm{Pt} / \mathrm{Ti}_{0.7} \mathrm{~W}_{0.3} \mathrm{O}_{2}$ electrocatalysts that not only $\mathrm{W}$ but also $\mathrm{TiO}_{2}$ contributes to the higher activity for $\mathrm{CO}$ oxidation on $\mathrm{Pt}$.

In Table 1 the values of the current density of the $\mathrm{CO}_{\text {ads }}$ oxidation at $710 \mathrm{mV}$ are presented. These values correlate well with the degree of $\mathrm{W}$ incorporation into the rutile- $\mathrm{TiO}_{2}$ crystal-lattice: the higher the extent of $\mathrm{W}$ incorporation, the higher the current density of the $\mathrm{CO}$ oxidation at $710 \mathrm{mV}$ is.

As seen from Fig. 5c, irrespective of the fact that carbon-free $\mathrm{Ti}_{0.7} \mathrm{~W}_{0.3} \mathrm{O}_{2}$ mixed oxide was successfully prepared and high degree of $\mathrm{W}$ incorporation into the $\mathrm{TiO}_{2}$ lattice was achieved, the intensity of the "pre-peak" and main peaks observed on the $\mathrm{Pt} / \mathrm{Ti}_{0.7} \mathrm{~W}_{0.3} \mathrm{O}_{2}$ catalyst (with $20 \mathrm{wt} \% \mathrm{C}$ added) was lower when compared to all $\mathrm{Pt} / \mathrm{Ti}_{0.7} \mathrm{~W}_{0.3} \mathrm{O}_{2}-\mathrm{C}$ catalysts. This may be due to difficulties observed upon deposition of Pt by the $\mathrm{NaBH}_{4}$-assisted EG reduction method on pure $\mathrm{Ti}_{0.7} \mathrm{~W}_{0.3} \mathrm{O}_{2}$ mixed oxide. This method of Pt deposition was extensively used for the preparation of highly dispersed carbon supported catalysts, but was quite ineffective in case of oxide supports. It has been demonstrated in Ref. [1] that the $\mathrm{Pt} / \mathrm{Ti}_{0.7} \mathrm{~W}_{0.3} \mathrm{O}_{2}$ catalyst with unique CO-tolerant property can be prepared by using the impregnation method followed by reduction in $\mathrm{H}_{2} / \mathrm{N}_{2}$ gas mixture.

On the PtRu/C bimetallic catalyst (Fig. 5b) the $\mathrm{CO}_{\mathrm{ads}}$ is oxidized over a broad potential region starting at potentials of ca. $300 \mathrm{mV}$ with current maximum at $810 \mathrm{mV}$. It is necessary to mention that the maximum of the main peak observed in this work was shifted to higher potential comparing to the values usually accepted in the literature (650-700 mV [1,8]).

The influence of the structure of the pure $\mathrm{Ti}_{0.7} \mathrm{~W}_{0.3} \mathrm{O}_{2}$ support and the $50 \mathrm{Ti}_{0.7} \mathrm{~W}_{0.3} \mathrm{O}_{2}-50 \mathrm{C}$ composite materials determined by XRD on the electrochemical performance of the catalysts in CO stripping is presented in Table 1. Electrochemically 
active surface area (ECSA) was calculated from the charge associated with a CO monolayer adsorbed onto the catalyst nanoparticles, assuming $420 \mu \mathrm{C} \mathrm{cm}^{-2}{ }_{\mathrm{Pt}}$ [81-83]:

$$
\frac{A}{m}=\frac{\frac{Q_{\mathrm{ge}}}{420 \mu \mathrm{cm}^{-2}}}{m}
$$

A challenge for the surface area determination by CO-stripping is the appropriate choice of integration limits and the subtraction of background currents, which are not connected with the CO oxidation [83]. In the present study the current of the base line voltammogram is subtracted in the potential region of the $\mathrm{CO}$ oxidation peak and the same integration limit between $0.60-0.85 \mathrm{~V}$ is used. According to Ref. [83], after background correction the remaining charge originates mainly from $\mathrm{CO}$ oxidation.

However, as it can be seen from Figure $6 \mathrm{a}$, on the $\mathrm{Pt} / \mathrm{Ti}_{0.7} \mathrm{~W}_{0.3} \mathrm{O}_{2}-\mathrm{C}$ catalysts the contribution of the "pre-peak" to the integrated coulombic charge $\mathrm{Q}_{\mathrm{CO}}$ compared to that of the main $\mathrm{CO}$ oxidation peak (measured between 0.60-0.85 V) was considerable. It has been demonstrated by Maillard et al. [9], that the charge under the pre-peak and the main electrooxidation peak (or peaks) is a function of the $\mathrm{CO}$ adsorption potential; if oxidation of adsorbed $\mathrm{CO}$ starts in the $\mathrm{H}_{\text {uph }}$ region, a clearly discernible pre-peak appears and the charge corresponding to the oxidation of the $\mathrm{CO}_{\mathrm{ads}}$ monolayer can be increased by ca. $40 \%$. However, upon ECSA calculation, due to the many uncertainties (difficulties to choose appropriate integration limits) the area of the "pre-peak" was not taken into account. Moreover, the upper integration limit for all $\mathrm{Pt} / \mathrm{Ti}_{0.7} \mathrm{~W}_{0.3} \mathrm{O}_{2}-\mathrm{C}$ catalysts was set to $0.85 \mathrm{~V}$. However, in some cases the main CO-stripping peak tails out at higher potential. The ECSA values calculated by these constraints are presented in Table 1. Based on the relative error (RE) values for the Pt ECSA (7-13\%) presented in Table 1 we can to conclude that the reproducibility of the electrochemical measurements was good. The values of the RE obtained were comparable with data presented in the literature for the real surface area measurements [83-85].

In interpretation of the ECSA values of Table 1, apart from the previously mentioned methodological issues, one should take into account that all measurements were made on catalysts activated by 100 cycles between 0.05 and $1.25 \mathrm{~V}$. Stability tests performed under the same potential range indicated structural changes (see below), thus the data cannot be related to the initial Pt particle size. Moreover, in case of the $\mathrm{Pt} / \mathrm{Ti}_{0.7} \mathrm{~W}_{0.3} \mathrm{O}_{2}-\mathrm{C}$ catalyst, the bifunctional mechanism requires an intimate interface formation between the Pt particles and the oxide, which should result in the decrease of 
the accessible Pt surface area. A similar phenomenon was described in Refs. 8 and 77, where encapsulation of $\mathrm{Pt}$ by $\mathrm{WO}_{\mathrm{x}}$ was reported.

The $\mathrm{CO}_{\mathrm{ads}}$ stripping voltammograms after Ar (Fig. 6a) and $\mathrm{H}_{2}$ purging (Fig. 6b) in the "pre-peak" potential range between 0.05 and $0.60 \mathrm{mV}$ were compared for the $\mathrm{Pt} / \mathrm{C}$, the $\mathrm{PtRu} / \mathrm{C}$ and the $\mathrm{Pt} / \mathrm{Ti}_{0.7} \mathrm{~W}_{0.3} \mathrm{O}_{2}-\mathrm{C}$ catalyst supported on the composite material prepared by synthesis route III. We have selected to enlarge this potential range as pronounced difference between the Ar-purged and $\mathrm{H}_{2}$-purged cases in the $\mathrm{CO}_{\text {ads }}$ stripping voltammograms was observed only here. We believe that the separate presentation of this $\mathrm{CO}_{\text {ads }}$ stripping voltammogram fragment allows showing in details the differences in the behavior of the samples. It is known $[8,77]$ that such experiments reveal the potential at which vacancies are formed in the $\mathrm{CO}_{\mathrm{ads}}$ monolayer. Once $\mathrm{CO}$ desorbs from a fraction of the catalytic sites, Pt sites become available for the dissociation/electrooxidation of $\mathrm{H}_{2}$ molecules resulting in a steep increase of the current up to the diffusion-limited plateau $[8,77,86]$.

As shown in Fig. 6a and 6b, on the $\mathrm{Pt} / \mathrm{C}$ catalyst the adsorbed $\mathrm{CO}$ blocks the $\mathrm{Pt}$ catalytic sites in the potential region studied, independently of the atmosphere used upon purging. On the contrary, the CO-tolerant catalysts behave differently in $\mathrm{CO}_{\mathrm{ads}}$ stripping after $\mathrm{Ar}$ and $\mathrm{H}_{2}$ purging. On the $\mathrm{PtRu} / \mathrm{C}$ catalyst after $\mathrm{H}_{2}$ purging a notable current increase was observed at about $350 \mathrm{mV}$ when compared to the Ar-purged situation. On the $\mathrm{Pt} / \mathrm{Ti}_{0.7} \mathrm{~W}_{0.3} \mathrm{O}_{2}-\mathrm{C}$ catalyst, purging the electrolyte with $\mathrm{H}_{2}$ results in an immediate and pronounced increase of the current in contrast to the Ar-purged case, translating the fact that a significant amount of vacancies are formed in the $\mathrm{CO}_{\mathrm{ads}}$ monolayer even in this low potential range. Based on these results, we can conclude that our catalyst supported on the $\mathrm{Ti}_{0.7} \mathrm{~W}_{0.3} \mathrm{O}_{2}-\mathrm{C}$ composite material performs better than benchmark catalysts such as $\mathrm{PtRu} / \mathrm{C}$ and our home made $\mathrm{Pt} / \mathrm{C}$. However, to distinguish between the current associated with the $\mathrm{CO} / \mathrm{H}_{2}$ electrooxidation process from the currents associated with the deinsertion of protons from the support and the double layer charging more detailed studies are needed.

A major issue concerning the catalyst support durability is carbon corrosion, which occurs at potentials that are higher than 0.9 V vs. RHE [87-90]. Electrochemical corrosion of the carbon supports causes the agglomeration and sintering of the $\mathrm{Pt}$ catalyst particles, which results in decreased ECSA of the catalyst [91-92].

Electrochemical stability of our best $\mathrm{Pt} / \mathrm{Ti}_{0.7} \mathrm{~W}_{0.3} \mathrm{O}_{2}-\mathrm{C}$ (route III) catalyst and the home made $\mathrm{Pt} / \mathrm{C}$ catalyst was compared by potential cycling between 0.05 and $1.25 \mathrm{~V}$ at 
$v=50 \mathrm{mV} \mathrm{s}^{-1}$ for 5000 cycles (Fig. 7). As shown in Fig. 7c, after 1000 cycles, the loss in the integrated Coulombic charge associated with hydrogen adsorption/desorption ( $\mathrm{Q}_{\mathrm{H}-\mathrm{UPD}}$ ) for $\mathrm{Pt} / \mathrm{Ti}_{0.7} \mathrm{~W}_{0.3} \mathrm{O}_{2}$-C was only $12 \%$, while it was $32 \%$ in case of the $\mathrm{Pt} / \mathrm{C}$ catalyst. After 5000 cycles, the loss in the $\mathrm{Q}_{\mathrm{H}-\mathrm{UPD}}$ was ca. $30 \%$ and above $70 \%$ for $\mathrm{Pt} / \mathrm{Ti}_{0.7} \mathrm{~W}_{0.3} \mathrm{O}_{2}-\mathrm{C}$ and $\mathrm{Pt} / \mathrm{C}$ catalysts, respectively.

(a) $\mathrm{Pt} / \mathrm{Ti}_{0.7} \mathrm{~W}_{0.3} \mathrm{O}_{2}-\mathrm{C}$ (route III)

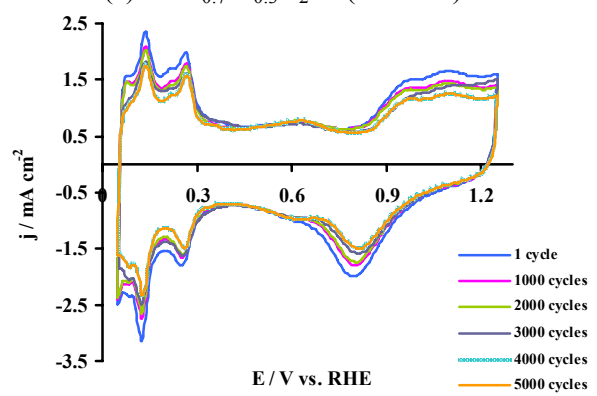

(b) $\mathrm{Pt} / \mathrm{C}$

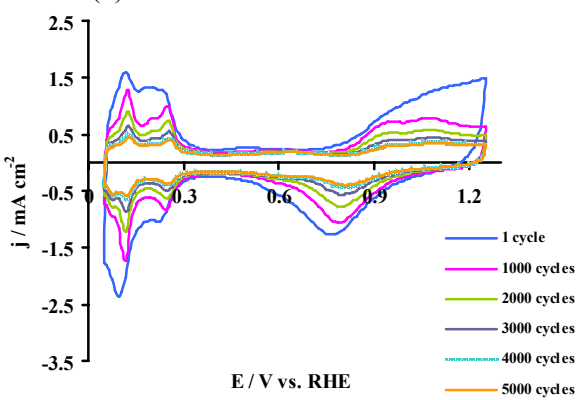

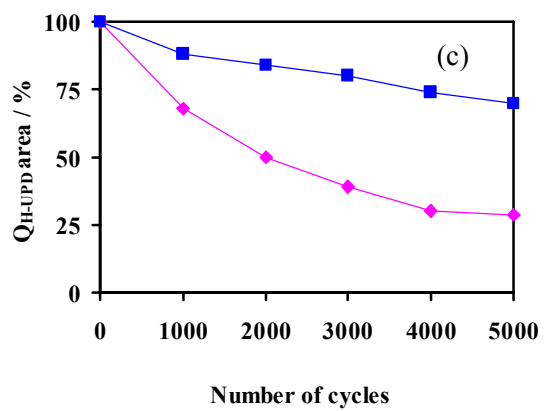

Fig. 7 Electrochemical stability study by cyclic polarization on (a) $\mathrm{Pt} / \mathrm{Ti}_{0.7} \mathrm{~W}_{0.3} \mathrm{O}_{2}-\mathrm{C}$ (route III) and (b) Pt/C catalysts, (c) comparison of the integrated Coulombic charge $\left(\mathrm{Q}_{\mathrm{H}-\mathrm{UPD}}\right)$ loss of $\mathrm{Pt} / \mathrm{Ti}_{0.7} \mathrm{~W}_{0.3} \mathrm{O}_{2}-\mathrm{C}(\boldsymbol{\nabla})$ and $\mathrm{Pt} / \mathrm{C}(\diamond)$ catalysts as a function of the number of cycles. Recorded in $0.5 \mathrm{M} \mathrm{H}_{2} \mathrm{SO}_{4}$ at $50 \mathrm{mV} \cdot \mathrm{s}^{-1}, \mathrm{~T}=25{ }^{\circ} \mathrm{C}$. The measurements took 66.7 hours. The $\mathrm{Q}_{\mathrm{H}-\mathrm{UPD}}$ charges, associated with hydrogen adsorption/desorption, were calculated using conventional baseline correction. The current density $\mathbf{j}$ was normalized to the geometrical surface area.

Similar stability test in the potential range between 0.05 and $1.1 \mathrm{~V}$ vs. RHE for 500 cycles was performed in Ref. [1] on $5 \mathrm{wt} \% \mathrm{Pt} / \mathrm{Ti}_{0.7} \mathrm{~W}_{0.3} \mathrm{O}_{2}, 20 \mathrm{wt} \% \mathrm{Pt} / \mathrm{C}$ and commercial E-TEK PtRu/C catalysts. After 500 cycles, the decrease of the $\mathrm{Q}_{\mathrm{H}-\mathrm{UPD}}$ over $\mathrm{Pt} / \mathrm{Ti}_{0.7} \mathrm{~W}_{0.3} \mathrm{O}_{2}$ and $\mathrm{PtRu} / \mathrm{C}$ catalysts was $5 \%$ and $30 \%$, respectively. According to these 
results we can conclude that the stability of our $\mathrm{Pt} / \mathrm{Ti}_{0.7} \mathrm{~W}_{0.3} \mathrm{O}_{2}-\mathrm{C}$ catalyst and the $\mathrm{Pt} / \mathrm{Ti}_{0.7} \mathrm{~W}_{0.3} \mathrm{O}_{2}$ catalyst presented in Ref. [1] was comparable.
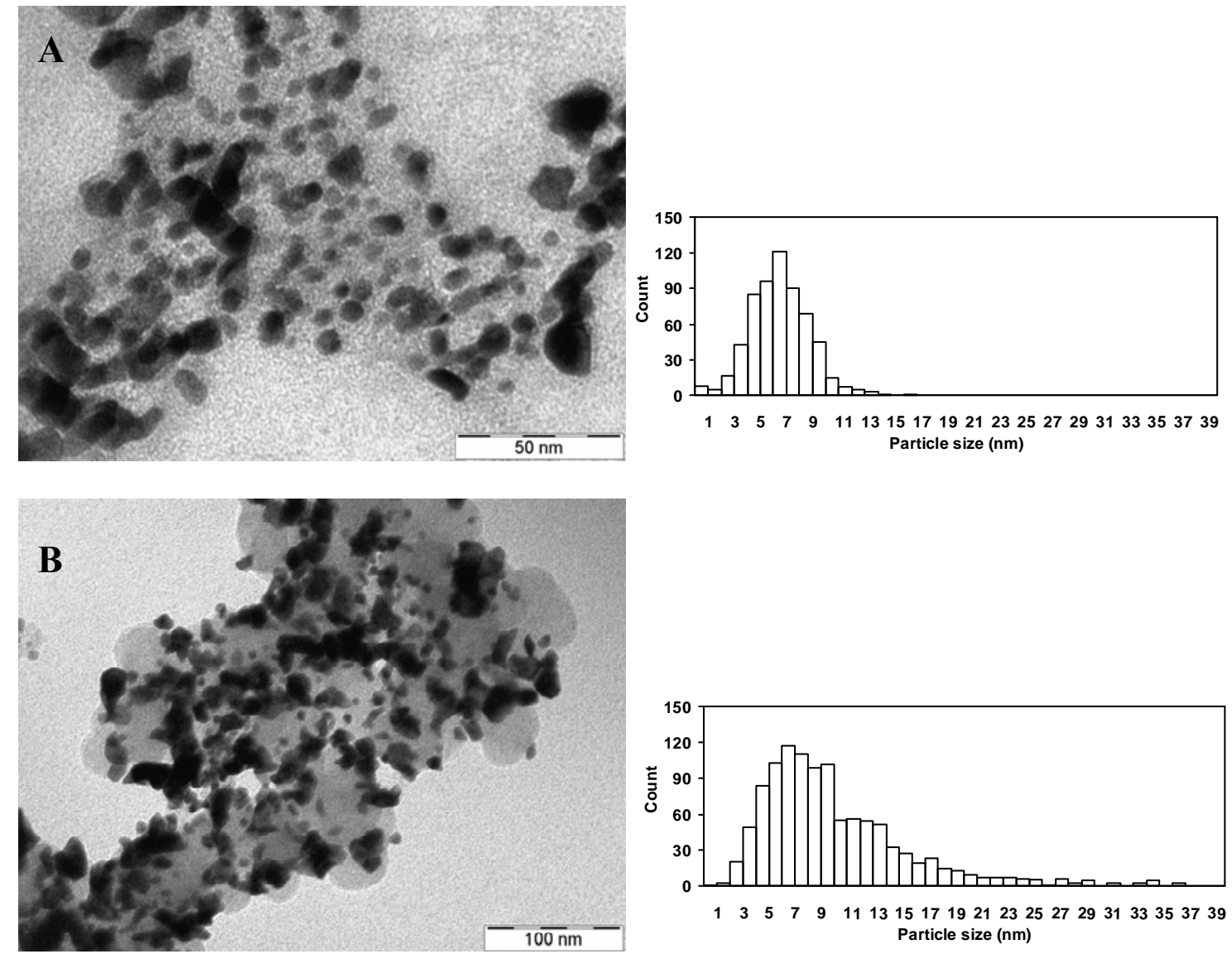

Fig. 8 TEM images and histogram of particle size distribution for (A) $\mathrm{Pt} / \mathrm{Ti}_{0.7} \mathrm{~W}_{0.3} \mathrm{O}_{2}-\mathrm{C}$ (route III) and (B) Pt/C catalysts after the electrochemical stability test experiments.

After electrochemical stability test experiments catalysts were removed from the electrodes with isopropanol in an ultrasonic bath and the Pt particle size distribution was verified via the TEM technique. After 5000 cycles, some extent of sintering and agglomeration of the Pt nanoparticles was observed for both catalysts (see Fig. 8; note the difference in the magnification). For the $\mathrm{Pt} / \mathrm{C}$ catalyst an increase of the $\mathrm{Pt}$ particle size from $4.5 \pm 1.8 \mathrm{~nm}$ to $10.0 \pm 5.7 \mathrm{~nm}$ was demonstrated. For the $\mathrm{Pt} / \mathrm{Ti}_{0.7} \mathrm{~W}_{0.3} \mathrm{O}_{2}-\mathrm{C}$ catalyst after 5000 cycles in the potential range between 0.05 and $1.25 \mathrm{~V}$ the main size of Pt particles was $6.5 \pm 2.3 \mathrm{~nm}$. This result confirms the stabilizing effect of the mixed oxide support on the Pt particles, rendering our $40 \mathrm{wt} \% \mathrm{Pt} / 50 \mathrm{Ti}_{0.7} \mathrm{~W}_{0.3} \mathrm{O}_{2}-50 \mathrm{C}$ (route III) 
catalyst to be a promising one as far as the electrochemical performance is considered. Ongoing experiments are aimed at decreasing the high Pt loading from $40 \mathrm{wt} \%$ to 20 $w t \%$. Concerning to the relatively low ECSA obtained on our catalysts the application of mesoporous carbon (MC) as a carbon support material can be very promising. The high surface area of MC allows for a fine dispersion of Pt nanoparticles, thus resulting in a large active catalyst surface [93]

Electrochemical evaluation, therefore, demonstrated that the electrocatalyst prepared using the $\mathrm{Ti}_{0.7} \mathrm{~W}_{0.3} \mathrm{O}_{2}-\mathrm{C}$ composite material with high degree of $\mathrm{W}$ incorporation synthesized upon using route III exhibited the best performance. Under conditions facilitating the degradation of the active carbon support our $\mathrm{Ti}_{0.7} \mathrm{~W}_{0.3} \mathrm{O}_{2}-\mathrm{C}$ composite materials were stable and the corresponding catalysts can be considered as promising ones. Enhanced $\mathrm{CO}$ tolerance, in certain aspects surpassing that of the $\mathrm{PtRu} / \mathrm{C}$ benchmark, along with considerable stability was established for this catalyst.

\section{Conclusions}

Electroconductive $\mathrm{Ti}_{0.7} \mathrm{~W}_{0.3} \mathrm{O}_{2}$-C composite materials were prepared by using three different sol-gel-based multistep synthesis routes: (i) a microwave-assisted solvothermal synthesis (route I), (ii) a sol-gel process (route II) and (iii) a modified lowtemperature sol-gel synthesis (route III). Preliminary formation of the rutile phase in the presence of activated carbon at room temperature has been proved to be prerequisite for complete $\mathrm{W}$ incorporation into the rutile- $\mathrm{TiO}_{2}$ lattice upon reductive treatment at $650^{\circ} \mathrm{C}$. As demonstrated by powder X-ray diffraction, upon using the synthesis route III high reproducibility in the formation of rutile phase with high crystallinity (98-100\%) and exclusive tungsten incorporation was achieved. Decomposition of the $\mathrm{W}$ precursor compound and its subsequent reduction was studied by TPR. In spite of the air exposure, incorporated tungsten was confirmed to be predominantly in the +4 oxidation state by XPS, in line with the TPR findings. Valence band spectra indicated the metallic nature of the tungsten doped rutile $\mathrm{TiO}_{2}$ phase. Homogeneous distribution of $\mathrm{Ti}$ and $\mathrm{W}$ atoms and coexistence of the mixed oxide with active carbon in 1:1 weight ratio was proved by EDS results for the $50 \mathrm{Ti}_{0.7} \mathrm{~W}_{0.3} \mathrm{O}_{2}-50 \mathrm{C}$ composite materials. The uniform distribution of highly dispersed Pt particles $(2.3 \pm 0.8 \mathrm{~nm})$ in $40 \mathrm{wt} \% \mathrm{Pt} / 50 \mathrm{Ti}_{0.7} \mathrm{~W}_{0.3} \mathrm{O}_{2^{-}}$ $50 \mathrm{C}$ anode electrocatalysts was verified via TEM technique. Enhanced CO tolerance of the electrocatalyst prepared using the $\mathrm{Ti}_{0.7} \mathrm{~W}_{0.3} \mathrm{O}_{2}-\mathrm{C}$ composite material with high degree of $\mathrm{W}$ incorporation (route III) was evidenced by the appearance of a CO- 
oxidation related "pre-peak" between 150 and $540 \mathrm{mV}$ and by a shift of the maximum of the main $\mathrm{CO}$ oxidation peak towards negative direction, from $820 \mathrm{mV}$ to about 710 $\mathrm{mV}$ on the $\mathrm{CO}_{\mathrm{ads}}$ stripping voltammogram. At the same time, better performance in the $\mathrm{H}_{2}$-purged $\mathrm{CO}_{\mathrm{ads}}$ stripping compared to the $\mathrm{PtRu} / \mathrm{C}$ benchmark and considerable stability for this electrocatalyst were also demonstrated.

\section{Acknowledgements}

The authors are grateful to the Hungarian Scientific Research Fund (OTKA, Grant №: K100793 and K77720) and the National Development Agency (Grant №: KTIA_AIK_12-1-2012-0014) for financial support. The authors thank Dr. I. Bakos for the interest and helpful discussion of this work.

\section{References}

[1] D. Wang, C.V. Subban, H. Wang, E. Rus, F.J. DiSalvo, H.D. Abruña, J. Am. Chem. Soc. 132 (2010) 10218-10220.

[2] L.G.S. Pereira, F.R. dos Santos, M.E. Pereira, V.A. Paganin, E.A. Ticianelli, Electrochim. Acta 51 (2006) 4061-4066.

[3] R. Ganesan, J.S. Lee, J. Power Sources 157 (2006) 217-221.

[4] A.C.C. Tseung, P.K. Shen, K.Y. Chen, J. Power Sources 61 (1996) 223-225.

[5] P.K. Shen, K.Y. Chen, A.C.C. Tseung, J. Electroanal. Chem. 389 (1995) 223-225.

[6] J. Zeng, J.Y. Lee, Int. J. Hydrogen Energ. 32 (2007) 4389-4396.

[7] A.C.C. Tseung, K.Y. Chen, Catal. Today 38 (1997) 439-443.

[8] F. Micoud, F. Maillard, A. Gourgaud, M. Chatenet, Electrochem. Commun. 11 (2009) 651-654.

[9] F. Maillard, E. Peyrelade, Y. Soldo-Olivier, M. Chatenet, E. Chaînet, R. Faure, Electrochim. Acta 52 (2007) 1958-1967.

[10] G. Nagy, R. Schiller, Int. J. Hydrogen Energ. 14 (1989) 567-572.

[11] E.I. Santiago, G.A. Camara, E.A. Ticianelli, Electrochim. Acta 48 (2003) 35273534.

[12] L.G.S. Pereira, V.A. Paganin, E.A. Ticianelli, Electrochim. Acta 54 (2009) 19921998.

[13] B. Rajesh, V. Karthik, S. Karthikeyan, K. Ravindranathan Thampi, J.M. Bonard, B. Viswanathan, Fuel 81 (2002) 2177-2190. 
[14] T. Xu, H. Zhang, H. Zhong, Y. Ma, H. Jin, Y. Zhang, J. Power Sources 195 (2010) 8075-8079.

[15] O. Lorret, D. Francová, G. Waldner, N. Stelzer, Appl. Catal. B: Environmental 91 (2009) 39-46.

[16] V. Samuel, R. Pasricha, V. Ravi, Ceram. Int. 31 (2005) 555-557.

[17] J.R. Perodeau, S.T. Munie, J.L. Hunting, in: Proc. The 237th American Chemical Society National Meeting, Salt Lake City, UT, (USA), March 22-26, 2009, abstract_153-INOR.

[18] R. D. Shannon, Acta Cryst. A32 (1976) 751-767.

[19] C.V. Subban, Q. Zhou, A. Hu, T.E. Moylan, F.T. Wagner, F.J. DiSalvo, J. Am. Chem. Soc. 132 (2010) 17531-17536.

[20] S.R. Dhage, Renu Pasricha, V. Ravi, Mater. Res. Bull. 38 (2003) 1623-1628.

[21] S.R. Dhage, V.D. Choube, V. Samuel, V. Ravi, Mater. Lett. 58 (2004) 2310-2313.

[22] K. Hayashi, M. Nakamura, Y. Makita, R. Fujiwara, T. Kori, K. Ishimura, Mater. Lett. 65 (2011) 3037-3040.

[23] A. Di Paola, G. Cufalo, M. Addamo, M. Bellardita, R. Campostrini, M. Ischia, R. Ceccato, L. Palmisano, Colloid Surface A: Physicochem. Eng. Aspects 317 (2008) 366-376.

[24] H. Cheng, J. Ma, Z. Zhao, L. Qi, Chem. Mater. 7 (1995) 663-671.

[25] Q. Chen, Y. Qian, Z. Chen, G. Zhou, Y. Zhang, Mater. Lett. 22 (1995) 77-80.

[26] R. Huirache-Acuña, F. Paraguay-Delgado, M.A. Albiter, J. Lara-Romero, R. Martínez-Sánchez, Mater. Charact. 60 (2009) 932-937.

[27] H.A. Therese, J. Li, U. Kolb, W. Tremel, Solid State Sci. 7 (2005) 67-72.

[28] X. Miao, Y. Yan, C. Wang, L. Cui, J. Fang, G. Yang, J. Power Sources 247 (2014) 219-227.

[29] S. Komarneni, R.K. Rajha, H. Katsuki, Mater. Chem. Phys. 61 (1999) 50-54.

[30] Z. Chen, W. Li, W. Zeng, M. Li, J. Xiang, Z. Zhou, J. Huang, Mater. Lett. 62 (2008) 4343-4344.

[31] S. Yang, Y. Liu, Y. Guo, J. Zhao, H. Xu, Z. Wang, Mater. Chem. Phys. 77 (2002) 501-506.

[32] S. Yin, R. Li, Q. He, T. Sato, Mater. Chem. Phys. 75 (2002) 76-80.

[33] J.H. Lee, Y.S. Yang, J. Eur. Ceram. Soc. 25 (2005) 3573-3578.

[34] Y. Li, N.H. Lee, E.G. Lee, J.S. Song, S.J. Kim, Chem. Phys. Lett. 389 (2004) 124128. 
[35] D.L. Liao, G.S. Wu, B.Q. Liao, Colloid Surface A: Physicochem. Eng. Aspects 348 (2009) 270-275.

[36] B. Gao, P.S. Yap, T.M. Lim, T.T. Lim, Chem. Eng. J. 171 (2011) 1098-1107.

[37] Y. Li, S. Zhang, Q. Yu, W. Yin, Appl. Surf. Sci. 253 (2007) 9254-9258.

[38] S. Qourzal, A. Assabbane, Y. Ait-Ichou, J. Photoch. Photobio. A: Chemistry 163 (2004) 317-321

[39] C. Moreno-Castilla, F. J. Maldonado-Hódar, F. Carrasco-Marin, E. RodriguezCastellón, Langmuir 18 (2002) 2295-2299.

[40] Z.Q. Song, S.B. Wang, W. Yang, M. Li, H. Wang, H. Yan, Mater. Sci. Eng. B 113 (2004) 121-124.

[41] S.B. Cho, J.S. Noh, M.M. Lencka, R.E. Riman, J. Eur. Ceram. Soc. 23 (2003) 2323-2335.

[42] T. Rádóczy, K. Kovács, Építőanyag, 58 (2006) 34-40.

[43] T. Putta, M.C. Lu, J. Anotai, J. Environ. Manage. 92 (2011) 2272-2276.

[44] J.H. Sun, Y.K. Wang, R.X. Sun, S.Y. Dong, Mater. Chem. Phys. 115 (2009) 303308.

[45] A. Kubacka, G. Colón, M. Fernández-García, Catal. Today 143 (2009) 286-292.

[46] M. Aryanpour, R. Hoffmann, F.J. DiSalvo, Chem. Mater. 21 (2009) 1627-1635.

[47] P. Kim, J.B. Joo, W. Kim, J. Kim, I.K. Song, J. Yi, J. Power Sources 160 (2006) 978-990.

[48] N. Fairley (2006) http://www.casaxps.com

[49] M. Mohai, Surf. Interface Anal. 36 (2004) 828-832.

[50] M. Mohai, (2003) XPS MultiQuant: Multi-model X-ray photoelectron spectroscopy quantification program, Version 3.00.16 http://www.chemres.hu/aki/XMQpages/XMQhome.htm

[51] C.D. Wagner, A.V. Naumkin, A. Kraut-Vass, J.W. Allison, C.J. Powell, J.R.Jr. Rumble, NIST X-ray Photoelectron Spectroscopy Database, Version 3.4, National Institute of Standards and Technology, Gaithersburg, MD, (http://srdata.nist.gov/xps/), 2003.

[52] J.F. Moulder, W.F. Stickle, P.E. Sobol, K.D. Bomben, Handbook of X-ray Photoelectron Spectroscopy, Perkin-Elmer Corp., Eden Prairie, Minnesota, USA, 1992.

[53] C.Y. Kim, J.W. Elam, M.J. Pellin, D.K. Goswami, S.T. Christensen, M.C. Hersam, P.C. Stair, M.J. Bedzyk, J. Phys. Chem. B 110 (2006) 12616-12620. 
[54] D.C. Vermaire, P.C. van Berge, J. Catal. 116 (1989) 309-317.

[55] E. Peters, H. Mueller-Buschbaum, Teil B. Anorganische Chemie, Organische Chemie 51 (1996) 29-31.

[56] F.J. Maldonado-Hódar, C. Moreno-Castilla, J. Rivera-Utrilla, Appl. Catal. A: General 203 (2000) 151-159.

[57] D.A.H. Hanaor, C.C. Sorrell, J. Mater. Sci. 46 (2011) 855-874.

[58] D. Gubán, I. Borbáth, A. Tompos, Z. Pászti, I. Sajó, E. Drotár, in: Proc. 11th European Congress on Catalysis (EuropaCat-XI), Lyon, France, 1-6 September 2013, abstract_0518.

[59] S. Eibl, B. C. Gates, H. Knözinger, Langmuir 17 (2001) 107-115.

[60] W. Grünert, R. Feldhaus, K. Anders, E.S. Sphiro, G.V. Antoshin, K.M. Minachev, J. Electron Spectrosc. Relat. Phenom. 40 (1986) 187-192.

[61] J. Engweiler, J. Harf, A. Baiker, J. Catal. 159 (1996) 259-269.

[62] D.S. Venables, M.E. Brown, Thermochim. Acta 285 (1996) 361-382.

[63] M.A. Alvarez-Merino, E Carrasco-Marin, J.L.G. Fierro, C. Moreno-Castilla, J. Catal. 192 (2000) 363-373.

[64] C. Moreno-Castilla, M.A. Alvarez-Merino, F. Carrasco-Marin, J.L.G. Fierro, Langmuir 17(2001) 1752-1756.

[65] D.S. Venables, M.E. Brown, Thermochim. Acta 282/283 (1996) 265-276.

[66] E. Lassner, W.D. Schubert, Int. J. Refract. Met. H. 13 (1995) 111-117.

[67] W.D. Schubert, E. Lassner, Int. J. Refract. Met. H. 10 (1991) 171-183.

[68] W.D. Schubert, E. Lassner, Int. J. Refract. Met. H. 10 (1991) 133-141.

[69] N. Rajalakshmi, N. Lakshmi, K.S. Dhathathreyan, Int. J. Hydrogen Energ. 33 (2008) 7521-7526.

[70] R.J. Colton, J.W. Rabalais, Inorg. Chem. 15 (1976) 236-238.

[71] K. Masek, J. Libra, T. Skála, M. Cabala, V. Matolín, V. Cháb, K. C. Prince, Surf. Sci. 600 (2006) 1624-1627.

[72] F.Y. Xie, L. Gong, X. Liu, Y.T. Tao, W.H. Zhang, S.H. Chen, H. Meng, J. Chen, J. Electron Spectrosc. Relat. Phenom. 185 (2012) 112-118.

[73] B.A. de Angelis, M. Schiavello, J. Solid State Chem. 21 (1977) 67-72.

[74] A. Warren, A. Nylund, I. Olefjord, Int. J. Refract. Met. H. 14 (1996) 345-353.

[75] F.H. Jones, R.G. Egdell, A. Brown, F.R. Wondre, Surf. Sci. 374 (1997) 80-94.

[76] O.Yu. Khyzhun, J. Alloys Compd. 305 (2000) 1-6. 
[77] F. Micoud, F. Maillard, A. Bonnefont, N. Job, M. Chatenet, Phys. Chem. Chem. Phys. 12 (2010) 1182-1193.

[78] S. Jayaraman, T.F. Jaramillo, S.H. Baeck, E.W. McFarland, J. Phys. Chem. B, 109 (2005) 22958-22966.

[79] F. Maillard, S. Schreier, M. Hanzlik, E.R. Savinova, S.Weinkauf, U. Stimming, Phys. Chem. Chem. Phys. 7 (2005) 385-393.

[80] M.S. Saha, M.N. Banis, Y. Zhang, R. Li, X. Sun, M. Cai, F.T. Wagner, J. Power Sources, 192 (2009) 330-335.

[81] P. Delahay, Double Layer and Electrode Kinetics, Interscience Publishers (Division of John Wiley \& Sons, Inc.), N.Y.-London-Sidney (1965).

[82] F.C. Nart, W. Vielstich, in: W. Vielstich, A. Lamm, H.A. Gasteiger (Eds.), Handbook of Fuel Cells, Electrocatalysis, vol. 2, Wiley, West Sussex, 2003, pp. 308-315 (and references therein).

[83] H. Schulenburg, J. Durst, E. Müller, A. Wokaun, G.G. Scherer, J. Electroanal. Chem. 642 (2010) 52-60.

[84] Y. Garsany, J. Ge, J. St-Pierre, R. Rocheleau, K.E. Swider-Lyons, ECS Transactions, 58 (2013) 3-14.

[85] K. Punyawudho, D.A. Blom, J.W. Van Zee, J.R. Monnier, Electrochim. Acta 55 (2010) 5349-5356.

[86] Z. Jusys, J. Kaiser, R.J. Behm, Phys. Chem. Chem. Phys. 3 (2001) 4650-4660.

[87] C. Subban, Q. Zhou, B. Leonard, C. Ranjan, H.M. Edvenson, F. J. DiSalvo, S. Munie, J. Hunting, Phil. Trans. R. Soc. A (2010) 368, 3243-3253.

[88] S.Y. Huang, P. Ganesan, B.N. Popov, Appl. Catal. B: Environmental 96 (2010) 224-231.

[89] S.Y. Huang, P. Ganesan, B.N. Popov, Appl. Catal. B: Environmental 102 (2011) 71-77.

[90] S.Y. Huang, P. Ganesan, B.N. Popov, ACS Catal. 2 (2012) 825-831.

[91] J.C. Meier, C. Galeano, I. Katsounaros, A.A. Topalov, A. Kostka, F. Schüth, .K.J.J. Mayrhofer, ACS Catal. 2 (2012) 832-843.

[92] S.Y. Huang, P. Ganesan, B.N. Popov, J. Am. Chem. Soc. 131 (2009) 13898-13899.

[93] A. Bauer, C. Song, A. Ignaszak, R. Hui, J. Zhang, L. Chevallier, D. Jones, J. Roziére, Electrochim. Acta 55 (2010) 8365-8370. 